\title{
O MUNDO NO QUAL O BRASIL SE INSERE HOJE: CAPITALISMO, INTERNACIONALISMO, SOCIALISMO
}

\author{
PEDRO PINCHAS GEIGER ${ }^{1}$ \\ Universidade Federal do Rio de Janeiro
}

A espécie é um real abstrato que se realiza por intermédio de seus indivíduos, estes sendo reais materializados. Porém, os indivíduos só se reproduziam através da espécie (LEFEBVRE, 1947). Do mesmo modo, as instituições humanas, como a família, a tribo, a nação, são coisas concretoabstratas, que se realizam por meio de seus membros individuais. Mas é pelas instituições que se realiza a reprodução da cultura dos indivíduos. $\mathrm{O}$ mundo também é um real concreto-abstrato que se realiza pelos lugares, pelos indivíduos e pelas instituições, que mantêm permanentes intercâmbios. Compreender um indivíduo, ou uma instituição, requer conhecer o mundo em que eles se inserem e seus intercâmbios. Compreender o Brasil, um ente geográfico socialmente criado, requer conhecer o mundo em que se insere e os laços que mantém com o mesmo. Esse é um dos sentidos do presente texto.

Acontecimento é o termo que expressa o aparecimento de um ser, de um objeto ou de um fato. Ocorre uma única vez (DELEUZE e GUATTARI, 1992). Um Moisés, um Platão, um Picasso aconteceram uma vez. A erupção do Vesúvio, com a destruição de Pompéia, aconteceu uma vez. O descobrimento do Brasil, em 21 de abril de 1500, também foi um acontecimento, ocorreu uma vez. Um acontecimento pode se identificar com um ato de imanência. Por exemplo, a invenção do tear, ou a invenção da máquina a vapor, é um ato de imanência. O acontecimento também pode resultar de um movimento de transcendência. A descoberta do Brasil transcendeu o movimento do intercâmbio que utilizava o caminho marítimo entre Portugal e as Índias.

${ }^{1}$ Geógrafo, Pesquisador Sênior do CNPq 
Acontecimentos, imanências e transcendências se integram em processos, nos quais exercem funções para seus desenvolvimentos. A rigor, o mundo passa por um processo único, universal, que teria se iniciado com o big bang. Desde então, esse processo foi se desdobrando em processos diferenciados, tornando o mundo cada vez mais complexo. O surgimento do homem desencadeou o processo social, que por sua vez passou a se desdobrar em diferentes subprocessos, cada um adquirindo graus de autonomia e, por isso, designados também, simplesmente, de processos. Os acontecimentos ocorrem, cada um, num devido lugar. Quanto aos processos, eles assumem dimensões locais, regionais ou universais. Vulcanismo é um processo universal que se manifesta em diversas regiões da Terra, mas cada erupção e cada vulcão se constituem num fenômeno local.

A solidificação do modo de produção capitalista foi um processo que dependeu da integração de acontecimentos, como a invenção da máquina, das formas de movimentos de intercâmbio entre Inglaterra, Flandres e Países Baixos e de suas extensões, abrangendo outras regiões e o mundo (MARX e ENGELS, 1996; WOOD, 2000). O intercâmbio estabelece elos entre acontecimentos e processos, entre imanências e transcendências, entre o singular, o particular e o universal. Ele move a história. A teoria marxista vê o processo como um complexo de interações, no qual se estabelecem contradições. O movimento do processo é então direcionado segundo as convergências e as divergências oriundas das contradições. A teoria marxista não aceita a ideia de fatores no processo social, uma vez que cada força social é influenciada por todas as outras. Aceita a ideia de uma hierarquia nas contradições, a existência de uma contradição maior e de contradições menores.

O Brasil, como um corpo, territorializado, apresenta dois lados. Um, o interior, é a fonte de forças imanentes produzidas pelas sociedades que foram sendo estabelecidas no território brasileiro. O outro, o exterior, exibe as relações internacionais, transcendentes, mantidas com o mundo exterior. A história do país é uma história da realização desses dois lados (RANGEL, 1981).

O momento atual mostra o Brasil vivendo uma transição acentuada, para a qual convergem e interagem as forças nacionais internas e as forças oriundas de suas relações internacionais. As forças internas se referem ao elevado grau de crescimento econômico e social do país. As forças externas se referem à densidade crescente das relações do país com outros 
países, em todas as instâncias. Dessa convergência e interação resulta o Brasil se elevar de posição no chamado mundo globalizado. Note-se que globalização não cobre apenas relações internacionais realizadas no nível das instituições. Elas incluem relações entre indivíduos pelas redes internacionais da internet. Os indicadores brasileiros quanto a domicílios providos de computador pessoal e quanto a acesso à internet figuram entre os maiores do mundo. O Brasil expande sua presença nos mercados mundiais econômicos e culturais, e se empenha na conquista de posição hierárquica mais elevada no concerto político internacional. O presente trabalho busca justamente focalizar as condições do mundo onde o Brasil está inserido. Um quadro a ser compreendido, ante as opções a serem tomadas pelos cidadãos e pelos governantes, frente a questões de natureza comercial, ideológica ou política. Particularmente agora, quando o mundo entrou numa fase de aguda recessão econômica e financeira desvelada desde meados de 2008. Uma crise que se reflete em todas as instâncias sociais e cuja saída trará, certamente, um mundo modificado economicamente, politicamente e geograficamente. A crise atual está sendo comparada, em termos de abrangência universal e dimensão das perdas de capital e empregos, à depressão mundial dos fins da década de 1920. Esta prolongou a recessão até desembocar na Segunda Guerra Mundial. A crise atual sucede a um longo período de inovações tecnológicas e de acumulação capitalista, iniciado no pós-guerra, embora entrecortado por momentos de recuos e de graves crises locais.

O texto, portanto, enfatiza aspectos das transições do modo de produção capitalista ocorridos desde os anos 1930 e dos ensaios diversos para a introdução de regimes de natureza socialista. Esses movimentos foram marcados pelo desenvolvimento de novas formas de colaboração internacional, entre governos, entre organizações públicas e privadas, e condutoras para uma nova ordem sistêmica denominada globalização. Desenvolvimentos que compreendem, igualmente, a persistência de conflitos de antiga origem, que se juntam a novos, para dar margem a movimentos antissistêmicos. Movimentos antissistêmicos que se dividem entre os que se opõe a qualquer forma de globalização, a qualquer tendência de maior mixagem de culturas e de internacionalização, e aqueles que se batem "por uma outra globalização".

O próprio termo globalização, com as raízes globo e ação, tem suscitado polêmicas. Correntes de historiadores têm contestado seu uso restrito à contemporaneidade, sob a alegação de que sempre existiram intercâmbios entre todos os pontos da Terra. Concedendo que até o século 
XVI as Américas e outras partes do mundo se encontravam fora dos circuitos normais, uma chamada corrente "quinhentista" admite o termo globalização válido apenas para depois dos grandes descobrimentos.

Contudo, são encontradas justificativas para o emprego restrito do termo globalização para os tempos atuais. Não apenas pela densidade e pela velocidade alcançadas pelas atuais redes sociais, conectando todos os tipos de instituições, e sustentadas pela informática e pelos satélites artificiais - que permitem, inclusive, transmissões "ao vivo". Nem pelos trilhões de divisas que circulam diariamente entre os principais mercados mundiais. Nem pelo fato de que massas anônimas se comunicam entre si, individual, nacional e internacionalmente. $\mathrm{O}$ argumento principal é muito simples. O termo globalização está internalizado na população comum, que o utiliza como a expressão de um mundo mais aberto e de intercâmbios em todos os níveis e em todas as instâncias.

A entrada de bilhões de indivíduos em sistemas de comunicação direta, via internet, evoca mensagem de Marx e Engels:

É exatamente esta união de indivíduos (pressupondo
naturalmente as atuais forças produtivas desenvolvidas) que
coloca sob seu controle as condições livres de
desenvolvimento e de movimento dos indivíduos - condições
que até agora encontravam-se à mercê do acaso (1996:112-
118). O ponto de vista do velho materialismo é a sociedade
civil; o ponto de vista do novo é a sociedade humana dar a
humanidade socializada (1996:128).

Os dois autores consideravam que qualquer modo de produção se move no sentido de atingir uma plenitude e formar uma totalidade. Totalidade representada pelo envolvimento de todas as instâncias sociais e por sua expansão no sentido de ocupar todo o planeta. Plenitude e totalidade a ser alcançada "no interior de um intercâmbio universal". O capitalismo teria amealhado o maior poder de força para atingir tal plenitude, porém não conseguiria ultrapassar um limite, dada a "falta de totalidade de capacidades”. Essa falta residiria na divisão interna do capitalismo, entre capitalistas individuais, de modo que só a introdução do socialismo traria as possibilidades de uma plenitude total, "através da eliminação de produtores individuais” (1996:105).

Compreende-se então a ideia de Marx e Engels quanto à mudança para o socialismo só poder se iniciar em um país de capitalismo avançado, 
mais próximo de totalidade, mas incapaz de alcançá-la por si mesmo. Embora não tivessem formalizado a expressão formação econômica $e$ social (SERENI e LUPORINI, 1974), ela estava implícita na concepção de Marx e Engels quando distinguem países de capitalismo mais avançado de outros, ou quando tratam de transições no capitalismo, na busca de uma plenitude ou totalidade. Como na declaração de que "a autonomia do Estado ocorre hoje em dia apenas naqueles países onde estamentos ainda não se dissolveram totalmente até se transformarem em classe” (1974:98). A opção de Marx e Engels pelo proletariado se fundamentava no fato de que este não teria nada a perder com seu despojamento de classe, tornandose o mais apto a liderar um movimento por maior humanização. Em suas visões do movimento social, os dois autores já introduzem a ideia de um sentido, tema central do pensamento heideggariano.

Compreendem-se, também, as deturpações originadas da ideia da totalidade e presentes na proposição totalitária, como se regimes censores de intercâmbios livres entre os homens pudessem alcançar alguma plenitude.

A instalação de um modo de produção não se dá no vazio. Ela se dá envolvendo estruturas sociais já existentes, a serem transformadas ou ajustadas. Transformações e ajustes são contínuos, produzindo o quadro histórico real de uma sociedade, a cada momento. Isto é, modo de produção se refere a formas estabelecidas nas relações sociais de produção de uma sociedade. No capitalismo elas separam proprietários de meios de produção, de um lado, e trabalhadores, operadores dos meios de produção, em troca de salários, do outro. Trata-se, portanto, de um modelo, abstrato. Já a formação econômica social expressa a realização concreta, materializada, do modo de produção, já que considera as interações que o modelo provoca em todas as instâncias. A formação apresenta, a cada momento, não só a evolução das formas resultantes dos encontros de um novo modelo de relações de produção com o quadro social herdado do passado, como a influência dinâmica do próprio processo, alterando continuamente os aspectos do modo de produção vigente. Considere-se, por exemplo, a expansão no capitalismo moderno do setor de gestores do capital e da produção. Estes não são operadores manuais, nem burocráticos, da produção, mas, também não são, propriamente, os proprietários dos meios de produção. Denominam-se de transições as fases pelas quais um mesmo modo de produção vai passando, através das alterações nas suas formações. Um aspecto da atual globalização consiste justamente no transbordamento do modelo do capitalismo americano sobre 
o mundo (HARDT e NEGRI, 2001). Modelo que Marx considerou "o exemplo mais acabado de Estado moderno" (MARX e ENGELS, 1996:98). Transbordamento que provocou fortes mudanças nas demais formações, conduzindo transições no capitalismo mundial.

Portanto, as formações econômicas e sociais se diversificam no espaço e no tempo. No interior de uma delas, pode ter início a germinação de um novo modo de produção cujo desenvolvimento dependerá de sua capacidade de expansão. Tal quadro tem levado a uma reassunção crescente da dimensão geográfica no pensamento da ciência social, necessária para a compreensão da história (SOJA, 1993). Nessa linha, Milton Santos propôs acrescentar a palavra espacial à designação da formação social: formação econômica, social e espacial. Julga-se tal medida, no entanto, imprópria, por criar na prática um pleonasmo O termo formação já significa movimento espacial e temporal. A palavra forma é a terceira pessoa do singular do presente do verbo formar e o substantivo forma (HEIDEGGER, 1966). Se acrescentar espacial, por que não acrescentar, também, e temporal?

\section{Transições no capitalismo. Surgimento do Estado socialista. A Segunda Guerra Mundial}

Desde os meados do século XIX acentua-se significativamente uma transição no modo de produção capitalista. Destaca-se a introdução do telégrafo, o crescimento crescente do setor financeiro e a presença do capitalismo americano. Por outro lado, em 1917, em meio à Primeira Guerra Mundial, nascia a União das Repúblicas Socialistas Soviéticas (URSS) ou União Soviética.

1. O crescimento do setor financeiro. O setor capitalista financeiro se concentrou inicialmente na Inglaterra, apoiado sobre a sua economia industrial exportadora. Londres se tornou o principal centro financeiro mundial e a maior metrópole mundial. Investimentos industriais passaram a fluir de países capitalistas para outros países capitalistas, assim como para suas colônias e para países independentes da periferia. A fábrica onde Marx colheu o material utilizado em $O$ capital, situada na Inglaterra, pertencia à família de Engels, na Alemanha.

No Brasil, no começo do século XX assistiu-se à entrada da empresa Light \& Power, com capitais iniciais de cerca de 10 milhões de dólares, na 
época o maior investimento estrangeiro no país. A novidade: o capital estrangeiro não se restringia mais à produção agroindustrial, a frigoríficos de carne, usinas de açúcar ou de óleo, o que já acontecia desde a segunda metade do século XIX. Nem se destinava apenas a equipar o país com ferrovias e portos para atender à exportação dos produtos de origem agrícola, ou mineral, consumidos nos países do centro. Agora o capital estrangeiro passava a participar do desenvolvimento urbano e industrial de um país periférico. $\mathrm{O}$ investimento da Light se voltou para as duas grandes cidades brasileiras da época, Rio de Janeiro e São Paulo, e se estendeu a capitais estaduais e diversas cidades médias, introduzindo energia, transporte, comunicações, água e esgoto urbanos. Mantendo monopólios sobre esses serviços durante anos, o carioca apelidou a Light - empresa de investidores americanos, ingleses e canadenses sediada em Toronto - de polvo canadense. A Light serviu de alvo no desencadeamento de movimentos nacionalistas urbanos, mas teve papel fundamental na modernização da vida urbana brasileira e na evolução de São Paulo e do Rio de Janeiro para se tornarem modernas metrópoles nacionais.

Observando o quadro europeu de pré-guerra dos anos 1930, é-se tentado a considerar que a chamada política de apaziguamento liderada por Chamberlain, em face das agressões cometidas por Hitler, já era a expressão do capitalismo financeiro. Mais internacionalista do que o capitalismo industrial nacional, o financeiro teria propensão maior para saídas negociadas de confrontos. A liderança nazista alemã certamente não avaliou corretamente o comportamento inglês em Munique, tomando-o apenas como sinal de fraqueza. Também não percebeu que a Inglaterra não era apenas mais um país europeu, com um império colonial. As enormes colônias de povoamento, Canadá e Austrália, eram como que suas extensões e faziam da Inglaterra, igualmente, um país extra europeu. Tal condição certamente influiu para que resistisse, mesmo quando se viu só na Europa, até a vitória final.

Após a Segunda Guerra Mundial, os Estados Unidos e a cidade de Nova York passaram a ocupar as posições de liderança do movimento do capitalismo financeiro.

2. O desenvolvimento do capitalismo na América do Norte. A industrialização dos Estados Unidos a partir do século XIX introduziu novas formas no modo de produção e na sua formação social. Essas formas começaram a transbordar sobre o mundo após a Segunda Guerra Mundial, dado o peso da presença política e dos investimentos americanos ao redor 
do mundo (HARDT e NEGRI, 2001). Entre as características trazidas pela formação capitalista americana, muitas são comuns a todas as nações americanas e se devem às condições semelhantes da colonização inicial do continente.

i. A imigração de populações e de capitais provenientes de outras partes do mundo. Uma vez que nenhum grupo étnico colonizador pode reclamar ancestralidade, a identidade nacional, em todas as Américas, deixou de se basear na linearidade, ou no sangue, e passou a se fazer por meio do lugar geográfico de nascimento - fato fundamental para desenvolvimentos ideológicos e políticos nos continentes americanos e no mundo atual.

ii. A dimensão territorial alcançada pelos Estados Unidos, coast to coast, do Atlântico ao Pacífico, propiciou a criação de uma primeira economia nacional industrial desenvolvida em escala continental. O formato em grande massa retangular oferece vantagem estratégica que, associada à posse de longas costas abertas sobre os dois maiores oceanos, deu ensejo para que país se tornasse, simultaneamente, um poder terrestre e marítimo.

iii. O deslocamento horizontal das populações no processo colonizador ofereceu possibilidades para a mobilidade social vertical, a ascensão de indivíduos em classe. O país se tornava uma válvula de escape de tensões de classe acumuladas na Europa, permitindo que emigrantes saíssem de pobreza extrema e que muitos enriquecessem. Uma enorme reforma agrária, por parcelamento de territórios que iam sendo conquistados a oeste das 13 colônias originais, realizada pelo governo federal instalado após a independência, contribuiu para a melhor distribuição da renda. Termos como self-made man, winners and losers, millionaire são criações da cultura americana.

iv. Em tal atmosfera social, a produção acabou se colocando à frente do consumo. Isso se deu mediante diversas estratégias voltadas ao estabelecimento de uma sociedade de consumo de massa, como: o modo fordista de produção industrial; salários mais altos do que na Europa, de modo a desencorajar consertos de objetos e estimular a compra de novos; o lançamento sucessivo de modelos novos de objetos fabricados; a introdução constante de novos objetos; o desenvolvimento da publicidade; e o incentivo de compras a crédito. Os alimentos passaram a ser industrializados, enlatados, empacotados, e se criaram os supermercados, os shopping, com suas vitrines sedutoras do consumo. O sistema do crédito 
contribuiu para a expansão bancária. O grupo Citi foi criado já em 1812, quando Napoleão se aventurava pela Rússia; o American Express existe desde meados do século XIX. No Manifesto de 1848, seus dois autores expunham dúvidas quanto a formatos sociais futuros, tendo em vista justamente a incógnita representada pelo desenvolvimento norteamericano, sem reminiscência de estamentos. Já tinham insinuado que no novo continente "nenhuma parte da população pode chegar a dominar as outras” (MARX e ENGELS, 1996:98). Marx passara algum tempo nos Estados Unidos, onde escreveu para o New York Times. Trocou correspondência com A. Lincoln e apoiando a guerra anti escravagista.

A diversidade da identidade nacional dos imigrantes nos Estados Unidos influenciou certamente as aspirações pela paz mundial, que passaram a crescer naquele país. A Liga das Nações, estabelecida após a Primeira Guerra Mundial, foi ideia do presidente Wilson. Se os Estados Unidos nem chegaram a nela ingressar, uma das razões foi sua discordância em relação aos termos duros impostos à Alemanha pelo Tratado de Versalhes. Prevendo o seu potencial para um novo conflito, uma das justificativas do nazismo em suas confrontações com a Entente Cordiale, a aliança franco-inglesa. Posteriormente, durante a Segunda Guerra Mundial, apesar de a maioria americana se posicionar a favor da Inglaterra, o máximo que Roosevelt conseguiu do Congresso foi o envio de armamentos financiados para aquele país, que se viu só, após a queda da França em 1940. Os Estados Unidos só entraram no conflito devido ao ataque japonês a Pearl Harbor, em 7 de dezembro de 1941.

Os novos aspectos do capitalismo americano compreenderam suas instâncias culturais e ideológicas, como o enorme desenvolvimento da publicidade para o consumo de massa, a popularização da comunicação por imagens, a difusão do cinema, da pop art, do jazz e de diferentes formas de dança, popular e erudita. A integração do popular e do erudito foi bem expressa na música de Gershwin. O movimento inovador continuou no pós-guerra, com a TV, ou com o estilo pós-moderno introduzido na arquitetura, e depois nas artes plásticas. A difusão de cartazes de propaganda estatal, produzidos com esmero artístico, e muito praticada na antiga União Soviética, foi influenciada por esse movimento de popularização da imagem no meio urbano..

Embora Heidegger (1966), em dado momento, justificasse a Alemanha hitlerista como representando a defesa europeia frente a culturas materialistas, a da América do Norte e a da União Soviética, o fato é que 
Hitler se voltou para a introdução na Alemanha de diversas realizações americanas, como a difusão do uso do automóvel, do Volkswagen, a construção das Autobahnen, rodovias comparáveis às highways, e o incentivo à indústria do cinema como instrumento de cultura ideológica nacional de massa. Hitler também procurou alargar a escala territorial da Alemanha, promovendo conquistas militares, e criar uma Europa como um continente submetido às regras germânicas. No entanto, marchou nach Ost, para o Este, onde os "peles-vermelhas" eram outros.

3. O surgimento de Estados socialistas e a bandeira da Internacional. Em novembro de 1917, numa Rússia esgotada pela guerra, ocorreu a chamada Revolução de Outubro (pelo calendário da Igreja Ortodoxa). Iniciada em São Petersburgo e liderada por Lênin, a revolução transformou o regime imperial da Rússia na União das Repúblicas Socialistas Soviéticas, o primeiro Estado fundado na ideia do modo de produção socialista.

Desde o século XIX o socialismo inspirou diversos movimentos ideológicos e políticos na Europa. O movimento comunista de Marx e Engels se mostrou o mais decisivo para provocar eventos como a revolução comunista na Rússia. No ambiente conturbado do fim da Primeira Guerra Mundial, ocorreram outras tentativas de revolução comunista, na Hungria, na Alemanha (com o grupo Spartacus, tendo Rosa Luxemburgo entre seus membros), mas que fracassaram. Na Ásia, na década de 1920, iniciou-se o movimento comunista armado chinês, igualmente num ambiente conturbado pelas agressões japonesas e por presenças imperialistas ocidentais. A revolução logrou se manter até alcançar o poder, em 1949.

Os termos do socialismo também foram apropriados por correntes políticas que nada tinham a ver com suas origens históricas. Como no caso do hitlerismo, que compôs a expressão Nationalsozialismus, nacionalsocialismo, nazismo. Exercício quantitativo interessante seria o de medir o uso de termos associados a socialismo desde os anos 1920 e segundo períodos cronológicos. Nos Estados Unidos, o New Deal de Roosevelt, plano para enfrentar a recessão dos anos 1930, introduziu o Social Security, a Seguridade Social. Depois, com a Guerra Fria, a palavra socialismo se tornou tabu nos USA, porém, vem tendo um novo ingresso no vocabulário do país, particularmente após a crise econômica de 2008-9.

Para Marx e Engels, o capitalismo, comparado a modos de produção anteriores, representava progresso, entre outras razões, por ter reduzido a 
autonomia do Estado e a influência dos estamentos que antes se encontravam em seu topo. No entanto, o capitalismo não atingiria a totalidade, função reservada ao socialismo (alvo possível ou meta assintótica?). A Ditadura do proletariado não seria uma proposta ao retorno do Estado autônomo, totalitário, mas a de criar uma condição na qual a classe proletária, ao assumindo a hegemonia do Estado, e tendo menos a perder, conduziria para a eliminação da classe e do Estado, e para o internacionalismo. Não se confundia totalidade com totalitarismo.

É realmente surpreendente o chamamento internacionalista, visionário, do Manifesto, num mundo sem internet e naves interplanetárias. Certamente cientes das limitações da época, seus autores não trouxeram um receituário amplo para a criação do socialismo. Eles citaram a nacionalização de bancos e ferrovias, o controle para um crescimento equilibrado das cidades. É interessante observar que o documento não inclui empresas de navegação. Provavelmente porque nesse caso não há necessidade de integrar, num mesmo empreendimento, o meio do transporte, a via do transporte e o controle de tráfego, como ocorre no sistema ferroviário..

O mundo real, porém, é muito mais complexo para permitir uma concepção final a seu respeito. Não fosse assim, não haveria a retomada contínua dos mesmos temas de pesquisa. Ao contrário do previsto, a revolução comunista se instalou primeiro num país de desenvolvimento capitalista menor, onde um tsar regia um Estado muito autônomo. O quadro social herdado pela Revolução facilitaria o recobrimento do comunismo pelo stalinismo. Ou seja, o stalinismo significou o tolhimento, ao extremo, da capacidade do comunismo russo incentivar o desenvolvimento de sociedades civis nas repúblicas soviéticas, para servirem de fontes de poder. Em vez disso, fez retornar o Estado autoritário r produziu o chamado socialismo real. Realidade que estancou a maior internalização de valores socialistas na população, apesar da propaganda estatal e proclamar estar criando um novo homem. O stalinismo negou as leis da hereditariedade genética de Mendel por razões ideológicas, assim como, proibiu a psicanálise de Freud. Este falava da permanência perene de Tanatos, morte, ao lado de Eros, amor, mas que o conhecimento poderia fazer crescer o controle sobre Tanatos (FREUD, 1975). Mendel e Freud apontavam para limites,algo inaceitável para o stalinismo. 
A conseqüência de tudo isso foi a extrema facilidade com que se deu a dissolução da União Soviética, na década de 1990. à míngua de maior apoio popular interno, mas provocando a maior comoção no mundo.

A União Soviética. É plausível pensar que a dimensão territorial ajudou a implantação do novo regime. Ao mover a capital para Moscou, resistiu melhor aos ataques contra revolucionários em suas periferias e que contaram com ajuda exterior. Vitoriosa, a revolução se utilizou da entidade imperial anterior, reunindo diversas etnias nacionais na União das Repúblicas Socialistas Soviéticas (URSS), como reafirmação de sua orientação marxista internacionalista. Esta União seria a etapa inicial de seta histórica na forma de capitalismo $>$ socialismo > comunismo internacionalista.

Pouco depois da morte de Lênin, no começo dos anos 1920, iniciouse a evolução para o stalinismo, com as atividades do Partido e do Estado ficando a reboque de confabulações palacianas maquinadas por Stalin. O Estado passou a adquirir características de entidade totalitária autônoma, controlando todas as instâncias sociais.

O jargão comunista tinha denominado seus membros a vanguarda das forças sociais voltadas para a introdução do socialismo. O termo vanguarda surgira também no meio das artes, desde os fins do século XIX, para designar movimentos que introduziam novas formas na produção artística, associadas aos novos conceitos na arte e sobre a arte. A antiga União Soviética dos anos 1920, em intercâmbio cultural com o Ocidente, apareceu como importante centro mundial, inovador nas artes plásticas, nas artes cênicas, no cinema, na poesia, na arquitetura, reunindo alinhados e não alinhados com as ideias comunistas e marxistas. A chamada escola construtivista, que daria origem ao estilo concretista, foi criada na URSS.

No entanto, o stalinismo passou a exigir uma cultura a serviço da propaganda do regime, fazendo abortar o movimento cultural livre, por meio da censura e do banimento. Separaram-se realismo social, no qual a arte incorpora o social e o político, e realismo socialista, no qual o social e o político incorporam a arte. Assim, acompanhando o último, a arte figurativa foi identificada com o realismo e o materialismo, enquanto a arte abstrata foi tachada de idealista e burguesa. Naturalmente, abriam-se as portas para a adulação e a mediocridade. Esse recuo cultural foi um dos motivos da ampliação do trotskismo em meios intelectuais mundiais, no Brasil representado por Mário Pedrosa, admirador do concretismo. 
A adulação surgida na instância artística se propagou às ciências, ao pensamento filosófico e político. Não se chegou ao racismo nazista, mas houve o charlatanismo de Lysenko durante anos, negando as leis genéticas de Mendel - este um judeu, em meio às estratégias antissemitas do stalinismo. Para se opor ao livre intercâmbio internacional das ideias, criou-se o termo cosmopolitismo, que seria um internacionalismo ruim, produzido no interesse do capitalismo. O totalitarismo stalinista não podia, no entanto, se despojar das origens, fazer, como a Alemanha nazista, discursos racistas explícitos, autos de fé primitivos com queima de livros em praça pública. Porém, o regime stalinista passou a valorizar os comportamentos morais tradicionais, a homenagear a família e condenar o amor livre, enquanto no Brasil, como em outros países, durante os anos 1930, e mesmo depois da guerra, o comunismo era apontado como a pregação da dissolução dos bons costumes e da família, da entrega dos filhos ao Estado, além de apátrida, propondo a entrega do país à Rússia "vermelha".

Grande divórcio entre a política soviética e princípios originais marxistas se manifestou no trato do intercâmbio. Após a guerra, mesmo tendo sido aliado e tendo contado com o apoio de Roosevelt contra Churchill em diversas questões políticas, Stalin manteve o Estado cerrado para o exterior. O intercâmbio favorece o novo. O stalinismo se comportava como o velho antes do tempo, temeroso, não confiando em seu próprio povo. Em troca, após a guerra, a União Soviética se envolveu, equivocadamente, em disputa por hegemonia mundial, com altos gastos militares, quando se via às voltas com a necessidade de reconstrução das enormes extensões territoriais arrasadas pelo conflito. Ficou com pouca margem para investir no consumo civil. O Estado enveredou por explorar e pressionar países de sua área de influência, provocando rupturas e revoltas. Romperam Tito, da antiga Iugoslávia, e Mao Zedong, da China. Passou a incentivar ou dar suporte a movimentos revolucionários, ou a regimes que se colocassem contra os interesses do centro capitalista, particularmente contra os Estados Unidos. Note-se que a estratégia preconizada por Trotski, banido da Rússia em 1929, também se restringia a ações políticas imediatistas, à "revolução permanente", a ser promovida em todas as partes do mundo. Bem diferente do que faz a China comunista na atualidade, desenvolvendo fantástico comércio internacional.

Para manter sua legitimidade e fazer crer que preservava o compromisso internacionalista, a Internacional foi mantida como hino do Estado. Até meados da guerra, quando se apelou para a “guerra patriótica”. 
Uma vez que setores bálticos, de bielorrussos e principalmente de ucranianos passaram a colaborar com o invasor alemão, apelou-se para a resistência nacional russa, vestida de vermelho. Foi mais uma manifestação de um jogo, que se aprofundaria no pós-guerra, no qual os governantes soviéticos seguiriam os interesses nacionais do Estado, enquanto externamente sua política era tida como de interesse para o internacionalismo socialista. Já anteriormente, até 22 de junho de 1941, quando os alemães desencadearam a operação Barbarossa, a invasão da União Soviética, a guerra era vista por amplos setores comunistas mundiais, segundo a retórica soviética, como uma guerra de interesses imperialistas. Uma salle de guerre, uma guerra suja para os comunistas franceses, que somente após a invasão da União Soviética deram outro colorido ideológico ao conflito e assumiram a Resistência.

Mantendo, internamente, uma sociedade estreitamente submetida a interesses palacianos de perpetuação, e, externamente, um campo de satélites dirigidos por comunistas, impondo práticas econômicas e políticas de exclusive interesse do Estado soviético, a dimensão ideológica, socialista e internacionalista foi perdendo credibilidade em seu próprio campo geográfico. No interior da União Soviética, multiplicavam-se os refusnik, uma expressão que mistura sons da língua inglesa e russa, e que se refere à recusa no meio intelectual esclarecido russo de aceitar o estado de coisas. Cresciam também os movimentos por autonomia entre as etnias não russas. Nos países da Europa Oriental e Central de regime socialista, este acabou se transformando em imposição soviética, mantido por colaboracionistas, e objeto de revolta popular. Nesse contexto, a implosão da União Soviética seria uma surpresa apenas no Ocidente.

A China substitui a União Soviética como superpotência comunista. Iniciado nos anos 1920, o movimento armado da revolução chinesa, sob a direção de Mao Zedong, alcançou o poder em $1^{\circ}$ de outubro de 1949. Diferia da revolução russa em diversos aspectos. Na antiga União Soviética, a revolução aproveitou o esgotamento russo com a Primeira Guerra Mundial. A Rússia, porém, não era propriamente um país derrotado, apenas saiu da guerra. A revolução, refletindo movimento ideológico urbano presente em toda a Europa, foi deflagrada na capital, ocupou logo o poder e se estendeu para ocupar o território. Sobrepôs-se ao antigo império, integrando variedade enorme de etnias, de bálticos a mongóis e turcomanos. Desse modo, o novo regime manteve a multiplicidade nacional em nome do ideal internacionalista. Na China a revolução comunista se moveu pelo campo, por três décadas, apoiada em 
massas camponesas, e deixou de ser o único alvo do governo nacionalista de Nanquim. Este se via às voltas com as sucessivas invasões japonesas, contra as quais as tropas comunistas, abastecidas pela União Soviética, também combatiam. Finalmente, depois da guerra, os comunistas se impuseram e ocuparam as grandes cidades.

Na China, a revolução passou a se identificar como reconquista de autoestima e como estratégia para uma nova integração. A China também se compunha de uma variedade de etnias, mas que estavam unidas desde os tempos milenares do Império do Centro e participando da cultura chinesa. Essa China vinha sendo dilacerada e humilhada por um Japão armado de tecnologia ocidental, que lhe arrancava regiões inteiras, e por imposições de potências ocidentais, inclusive criando enclaves exclusivos em suas principais cidades. Caberia à revolução integrar aquele passado rico da China à modernidade ocidental, em todas as suas instâncias.

Para alcançar esse propósito, seria necessário superar o modelo stalinista. Foi normal que, num país majoritariamente rural, se reproduzisse inicialmente o tradicional autoritarismo e fosse implantado o "culto à personalidade” a Mao. O líder chinês introduziu a ideia de que a natureza dos países periféricos ante o centro capitalista reproduzia à natureza das classes periféricas frente à classe capitalista. Essa seria a razão de a revolução comunista não se iniciar no centro, como previsto por Marx, mas em sua periferia, onde a classe capitalista e a classe média eram mais fracas e a ideologia burguesa menos injetada na sociedade. Tais argumentos justificariam os cortes de intercâmbio com os países capitalistas.

Todavia, entre avanços e recuos, a China acabou se abrindo para o intercâmbio comercial com os países capitalistas e para a absorção da cultura ocidental, enquanto construía um novo ambiente urbano e industrial. Linhas de ação que impediram a formação de uma nova "cortina de ferro", e que se realizaram em meio a agudos debates e lutas pelo poder no Partido e no Estado, com a vitória, entre outros, de Zaho Ziyang e de Deng Xiaoping. A China ainda mantém um regime autoritário, para os moldes das democracias capitalistas, porém já mais brando. A questão quanto ao futuro próximo é se ele trará maior ocidentalização da China ou um ambiente mundial mais autoritário.

Há a considerar outras particularidades chinesas. Como a ausência de idealismos associados a uma religião coercitiva; uma história de intensas atividades comerciais com pacientes práticas de negociações; a criação de 
enorme diáspora, de dezenas de milhões espalhados pelo mundo, localizadas principalmente em cidades-metrópole, e envolvida em atividades comerciais. Chineses, como judeus, se adaptam bem a qualquer ambiente livre de xenofobia e tendem a manter a identidade original. A estrutura social tradicional fundada em famílias, e que procede de tempos profundos, influi certamente no comportamento chinês de assumir a cidadania dos países em que nascem sem perder a identidade chinesa e de manter ligações com o país de origem. Chineses, como judeus, guardam os mais antigos calendários e cultuam fundadores biológicos ancestrais, uma força de permanência de identidades milenares.

As relações entre a China e sua diáspora, a importância dos investimentos da diáspora direcionados para o país de origem, certamente influenciaram sua abertura econômica da China para o mundo. Outros fatos vividos pela China mostram o seu entendimento da complexidade e do hibridismo presentes no mundo contemporâneo. Como a manutenção da economia capitalista de Hong Kong, após a sua re-incorporação; ou a procura de uma solução negociada para uma reunificação com Formosa, na base de "um país, dois regimes"; e na proposição de um socialismo de mercado. Ao contrário da União Soviética, a China comunista se vale das forças de economia privada para o crescimento econômico e da participação de investimentos de empresas estrangeiras (ZENIN, 2002). Como se seguisse as ideias da Ideologia alemã, ou as de Nicos Poulantzas (MARTIN, 2008), para quem o essencial do socialismo é o regime de partido político único. Para Poulantzas, a classe burguesa pode ampliar as suas concessões na área econômica, mas não pode abrir mão da pluralidade partidária. A China não se concentra em propaganda ideológica verbal para alargar sua influência no mundo, mas na força de seus intercâmbios econômicos e de suas realizações.

No entanto, a principal diferença entre a antiga União Soviética e a atual China Comunista reside certamente no fato de que esta se instalou somente em meados do século XX, desse modo dispondo de uma distância crítica, para aprender com os erros da primeira. E avaliar as novas teorias contemporâneas, relativas à complexidade, à irreversibilidade, à indiferença, entre outras.

O crescimento brasileiro vem se apoiando em articulações cada vez mais com a expansão chinesa, através da intensificação do comércio bilateral e dos investimentos brasileiros naquele país, como na indústria aeronáutica. A China é atualmente o maior produtor mundial de aço, e 
grande parte de seu minério é fornecida pela Vale. O exemplo chinês influi no declínio, em setores da esquerda, de ideias radicais de ruptura traumática com o capitalismo e a globalização.

4. Capitalismo degenerado, formas fascistas. O avanço tecnológico e industrial, promovendo desde o século XIX a aceleração demográfica e a concentração urbana, introduziu a massificação - palavra criada para caracterizar a afluência de enormes massas populares para atividades políticas e culturais, antes mais restritas às classes superiores. Porém, ao contrário de termos como consumo de massa e inclusão social, massificação, apesar de também ser associado a democratização, é empregado frequentemente com sentido depreciativo. Por expressar uma incorporação acelerada de populações que se encontravam excluídas, ela pode baixar, por um dado período, os níveis médios de atividades culturais e acadêmicas. Ou pode servir a manobras de grupos políticos para a introdução de regimes demagógicos ou totalitários, ao chamado populismo. Este termo descreve um quadro no qual, em troca de pequenas melhoras pecuniárias ou ambientais, as populações de baixa renda oferecem a lealdade e o voto a políticos provedores dessas melhoras. O populismo não é propriamente fascismo, mas pode facilitar seu caminho. Durante a aceleração da urbanização brasileira iniciada por Vargas e que deu margem a movimentos populistas, o humorista brasileiro Barão de Itararé escreveu que, "cada vez mais, os vivos são governados pelos mais vivos".

A insatisfação social com o quadro econômico capitalista após a Primeira Guerra Mundial deu margem a movimentos políticos dirigidos por líderes que aproveitavam as massas imbuídas de sentimentos anticapitalistas, de chauvinismos nacionalistas e de preconceitos anticomunistas. Nascia o fascismo formalizado em partidos políticos, cuja agressividade crescia até proporcionar a ignição da Segunda Guerra Mundial. A primeira instalação de um Partido Fascista no poder estatal se deu na Itália, em 1922. O fascismo identificava o capitalismo liberal, criador de classes, como a origem do mal-estar econômico e social. O comunismo, porém, seria ainda mais maléfico, dissolvente de valores morais e colonizador a serviço dos dirigentes russos.

O nome de Partido Fascista na Itália vinha de fascio, feixe, antigo símbolo romano, para simbolizar a força do "povo unido". O fascismo se dizia destinado a superar a estrutura de classe, pela submissão da classe ao nível mais alto do Estado, criando-se uma totalidade nacional dirigida pelo Estado. Por isso, necessitava a submissão de toda a sociedade ao partido 
único e a sua aceitação do fim da liberdade de pensamento e de crítica. O olhar para trás, para o classicismo do passado, reintroduzindo mitos e símbolos, servia para reforçar o conservadorismo, mas também para atrair intelectuais da estatura de um D’Annunzio. A Itália alimentava o retorno imperial da antiga Roma, expulsar a esquadra inglesa do Mediterrâneo, de novo mare nostrum.

O fascismo alemão, o nazismo, também se declarou, retoricamente, contra a estrutura de classe, criticando o comportamento pequeno-burguês, atingindo tanto os princípios democráticos, como colocando a burguesia industrial a serviço dos interesses do Estado. Na verdade os regimes fascistas implantados expressaram um conluio, do qual participaram líderes provenientes de todas as classes sociais, inclusive da aristocrática. As classes eram mantidas atrás do biombo do Estado. Na Itália, a monarquia foi mantida e o genro de Mussolini, no cargo de ministro do Exterior, foi agraciado com o título de conde Ciano. O país retornou à formação de corporações representativas das classes produtoras para participarem do processo estatal, político e de gestão Na Alemanha, Hitler foi escolhido pelo velho marechal prussiano Hindenburg como seu sucessor. À alta burguesia capitalista, caberia produzir para sustentar os objetivos estratégicos definidos pelo Estado: crescimento econômico, hegemonia internacional e expansão territorial, assim justificando a manutenção do poder nas mãos do grupo e do ditador do dia. O fascismo inflou o interesse nacional a tal ponto que se tornava aceitável qualquer agressão moral em seu nome, inclusive a conquista de outras nações pela guerra - processo iniciado por Mussolini contra a Abissínia, em1935. Daí o título de capitalismo degenerado.

Na Alemanha, a implantação do nazismo se valeu, além da crise econômica, do revanchismo deixado pela Primeira Guerra Mundial. Em 5 de janeiro de 1919 foi fundado, em Munique, o Partido dos Trabalhadores Alemães, que ano depois passou a se chamar de Nacional-Socialista dos Trabalhadores Alemães. Nazismo deriva de Nationalsozialismus em alemão. O fascismo se apoderava do termo socialismo. Como diria Chacrinha, ele "veio para confundir, não para explicar". Em 1933, o partido nazista ascendeu ao poder e rapidamente a Alemanha se tornou líder dos países fascistas.

O nazismo mobilizou mitos germânicos, elegeu símbolos do classicismo grego e romano para suas ações e levou o preconceito racial e o chauvinismo nacional, o Deutschland über alles, ao mais alto grau. O 
liberalismo permissivo do capitalismo teria possibilitado que raças inferiores, particularmente a mais perniciosa, a judaica, penetrassem o capitalismo dos países democráticos, tornando-o plutocrático e internacionalista. Os judeus também eram responsabilizados pela introdução das ideias socialistas marxistas e do comunismo no mundo. O irônico do anti-semitismo alemão é que ele ocorria no país onde os judeus mais se assimilavam e contribuíam para a cultura do país. No entanto, o antissemitismo serviria ao propósito ganhar adeptos entre massas com velhos preconceitos arraigados.

Contudo, para o fascismo é cada nação por si. A nação alemã era superior às outras e precisava preservar sua pureza, abominando mestiçagens que solapariam sua unidade nacional. Por meio do nazismo seria criada uma economia a serviço do povo, subordinada ao Estado da raça superior, e por isso merecedora de pilhagens imperialistas, de ocupações de territórios de outros países para seu Lebensraum, seu espaço vital. O fato de a Polônia ser governada nos moldes fascistas não impediu sua invasão pela Alemanha. Posteriormente, já depois da guerra, quando regimes militares fascistoides (sem "narrativas" formais de fascismo) se instalaram na América do Sul, Argentina e Chile quase foram à guerra, pelo canal de Beagle, e a Argentina tentou ocupar as ilhas Malvinas à força.

O Japão. O Japão esteve fechado ao mundo até o século XVIII. Quando entrou na arena mundial, demonstrou alta capacidade de absorver rapidamente a tecnologia ocidental, enquanto mantinha a estrutura social em moldes tradicionais e conservadores. Sua necessidade de matériasprimas para sua industrialização foi uma das motivações de suas agressões imperialistas, ocupando a Coreia e desmembrando a China. Desinteressado de redigir ideologias formais para o mundo, como o Mein Kampf (Minha luta), de Hitler, o comportamento da formação japonesa afinava, no entanto, com as práticas do fascismo e desembocou na formação do Eixo, a aliança alemã, italiana e japonesa, dirigida inicialmente contra a União Soviética, Atritos militares entre soviéticos e japoneses eram frequentes nos anos 1930 na fronteira entre a Manchúria, ocupada pelo Japão, e a Sibéria.

As barbáries praticadas pelos japoneses na China foram de uma escala que tem dificultado até hoje a reconciliação do povo chinês. Nos anos 1930 os Estados Unidos impuseram um bloqueio para as exportações de petróleo ao Japão, para forçá-lo a parar com a extensão de suas 
conquistas de território chinês, o que acabou provocando Pearl Harbor e a entrada de ambas as potências na Segunda Guerra Mundial.

5. A difusão das ideologias pelo mundo. Os países do centro, URSS incluída, se empenharam em difundir suas ideologias pelos países periféricos e assumir ascendência sobre os mesmos. A revolução fascista na Espanha (1936-38), liderada por Francisco Franco, se tornou um marco de intervenção estrangeira nos confrontos internos nacionais. A guerra espanhola colocou em causa o princípio da intervenção em defesa de países atacados do exterior. A intervenção já fora defendida pela URSS em 1935, na Liga das Nações. E depois, ante a militarização alemã, quebrando cláusulas do Tratado de Versalhes, quando Litvinov ainda era seu ministro do Exterior. Quadro distinto do que foi visto quando da ocupação do Kuwait pelo Iraque, em 1991. A URSS e a esquerda pediam ação contra Mussolini, quando invadiu a Abissínia, atual Etiópia, apesar da natureza anacrônica vivida por esse país, cujo imperador Selassie (que o carnaval brasileiro transformou em Sei lá se é) era carregado em liteira e abanado por serviçais. Enquanto Mussolini era o "ditador esclarecido", que saneara o vale do Pó, onde se instalaram enormes arrozais, objeto do filme clássico Arroz amargo (1949). Ante a impotência anglo-francesa de ajudar os republicanos espanhóis, atacados por soldados italianos e aviões alemães (Guernica), apesar de a França ser governada pelo Front Populaire, liderado pelo socialista Leon Blum, organizaram-se as "brigadas internacionais”, com voluntários de diversas partes do mundo. Entre eles, brasileiros, americanos, como o escritor Hemingway, e outros, que foram lutar pelos republicanos.

Nos países periféricos de forte urbanização e massificação, as ideologias comunista e fascista encontravam eco, dada a agitação já existente em torno de interesses nacionalistas, que debitavam o atraso de seus países à presença dos capitais e das ideologias procedentes do centro capitalista. Ou dada a agitação já existente por causa das reivindicações de classes populares e médias. Naturalmente, nos países periféricos, majoritariamente rurais, com forte presença da religião, seria mais fácil a grupos governantes se apropriarem de posições próximas ao fascismo, que permitiam a manutenção da estrutura de classe e sem o compromisso temido com a URSS. Nesses casos, era reforçado o papel do Estado intervindo na economia e atendendo a um número de reivindicações trabalhistas e de melhoramentos dos ambientes urbanos de áreas populares e de populações pobres - em troca da aceitação da redução das liberdades da democracia burguesa, da imposição do totalitarismo e da perpetuação 
dos governantes no poder. Sucessos econômicos obtidos ajudavam a manutenção do esquema. Desse modo se organizaram as formas mais extremas dos regimes populistas.

No Brasil, durante os anos 1920 foi fundado o Partido Comunista Brasileiro. Este participou inicialmente da formação da Aliança Libertadora, que levou Getúlio Vargas ao poder. Na década seguinte, surgiu o Partido Integralista, de orientação fascista. Plínio Salgado, seu dirigente máximo, era denominado chefe, correspondente a Führer. Camisa verde, em lugar da parda, o símbolo sigma, em lugar da cruz gamada, o braço estendido saudando anauê, termo indígena, em vez de heil Hitler, faziam parte do ritual.

O governo Vargas, no entanto, não se deixou envolver pelos comunistas e integralistas Ele se aproximou do fascismo e de seus regimes totalitários por conta própria. O Eixo lhe acenava trocar produtos manufaturados por matérias-primas, sem que o país necessitasse gastar divisas. A Constituição de 1937, redigida por Francisco Campos e outorgada por Getúlio, para reger o Estado Novo, foi alcunhada de Polaca, dada a semelhança com a da Polônia. O regime, inspirado no corporativismo italiano, criou uma série de organizações patronais. Ao começo da Segunda Guerra Mundial, o Brasil mostrou simpatia pela Alemanha. Só mudou de lado, se alinhando com os Estados Unidos, em seguida a Pearl Harbor. Getúlio só foi apeado do poder em 1945, depois da guerra, e depois do "curto período de 15 anos" - pouco menos que a ditadura militar iniciada em 1964.

6. Teorias sobre guerras mundiais. Segundo Marx e Engels, "as colisões na história têm origem na contradição entre as forças produtivas e a forma de intercâmbio" (1996:115). Após a Segunda Guerra Mundial, círculos marxistas atribuíram as guerras mundiais à necessidade de destruir meios de produção e populações produtivas para o interesse capitalista de reequilibrar dimensão de capacidade produtiva com relações de produção. A tese servia para lançar sobre os países capitalistas a responsabilidade pelos conflitos armados locais e por uma anunciada Terceira Guerra Mundial - que nunca ocorreu. O ponto mais próximo de uma hecatombe ocorreu em 1962, quando da crise dos balísticos soviéticos instalados em Cuba. Kennedy ameaçou retirá-los à força, mobilizou a esquadra e Kruschev recuou e os retirou.

Historiadores argumentaram contra a teoria apresentada acima, considerada mecanicista. Foi exposta a influência cultural, exercida pela 
aristocracia, que continuava a ocupar posições na direção dos Estados. A aristocracia trazia as tradições de luta física, desde os tempos da cavalaria e de suas lides armadas. O comportamento diferenciado de oficiais de estirpe aristocrática e soldados da burguesia, durante a Primeira Guerra Mundial, é apresentado magistralmente no filme A grande ilusão, de Jean Renoir (1937).

No processo social, normalmente, não atua um único fator, ou fatores isolados, mas a interação de vários desenvolvimentos (WOOD, 2000). Desse modo, ambas as ideias expostas são aceitáveis e descrevem diferentes momentos - como quando se põe em marcha um automóvel. É necessário o manejo inicial da chave de ignição, mas, para o carro se mover, ele depende do estado de toda a sua estrutura. O assassinato do herdeiro de Franz Josef ao trono do Império Austro-Húngaro em Sarajevo deflagrou a Primeira Guerra Mundial, mas foi apenas a fagulha, num quadro político propício.

O arrefecimento continuado da Guerra Fria, depois de 1962, mostrou a força de dissuasão do terror atômico e a propensão a negociar do capitalismo avançado e de um comunismo pós-stalinismo. As guerras de escala mundial capazes de eliminar nações foram substituídas por guerras entre gigantescas corporações transnacionais, capazes de devorar umas às outras, e por conflitos armados de escala local, transferidos para as periferias, embora envolvendo grandes potências - por exemplo, na ajuda a um parceiro ou na ação conjunta de apagar o incêndio que ameaça fugir ao controle.

A paz pode ser figurada como uma planície. Nesta, as águas correntes fluem lentamente, depositam sedimentos e se subdividem por anastomose. Do mesmo modo, na paz as correntes ideológicas tendem a se dividir em inúmeras subcorrentes. A guerra é como a encosta íngreme, na qual as águas tendem a se encaixar em caneluras. As subcorrentes ideológicas devem ceder a alinhamentos singelos em luta. A Segunda Guerra Mundial funcionou como encosta íngreme, com as três grandes correntes citadas - democracia capitalista, socialismo, fascismo. Depois da guerra, após um primeiro intervalo, voltaram os diversos desdobramentos ideológicos. 


\section{Transições para a globalização}

Finda a Segunda Guerra Mundial, surgiu um novo mundo, e uma nova correlação de forças passou a se mover até chegar ao momento atual. Cada presente deste movimento continha todo o seu passado, e o seu futuro em estado virtual. Um processo povoado simultaneamente por inovações e acontecimentos e pela ressurgência de antigas culturas e práticas.

O fantástico nível técnico alcançado pela humanidade é o marco mais impressionante da atualidade. Ele dá continuidade a uma aceleração iniciada com os esforços de guerra, quando foram inventados o avião a jato, o radar, o computador eletrônico, o balístico, a utilização da energia atômica, o antibiótico, entre outros. Antes de surgir o termo globalização, Manuel Castells (1989) propusera definir uma Era da Informação e um conceito de modo de desenvolvimento, identificado como modo da informatização. Sem a web, a rede, a serviço de corporações, órgãos de pesquisa, instituições públicas, sociedades civis e pessoas físicas, a atual forma de globalização e de internacionalismo seria impensável. O progresso tecnológico envolve todas as instâncias sociais, fez o planeta "encolher" e inaugurou a aventura interplanetária.

O nível alcançado pelo progresso tecnológico fez Heidegger ver, no mesmo, a maior aproximação ao real, capaz de dar fim à Filosofia. Spielberg viu a possibilidade da entrada no surreal, com Parque dos dinossauros. No entanto, quando o homem pisou na Lua, houve certo desconforto na percepção de que não se encontrava nada sobrenatural fora da Terra. A humanidade participa da construção de um mundo cada vez mais complexo, mas que não transcende, nem alcança totalmente o real, tantas vezes sonhado. Como sugerido no antológico 2001, Uma odisséia no espaço (KUBRICK, 1968), que transmite o estranho sentimento paradoxal, de que tudo muda, enquanto tudo continua a mesma coisa - plus ça change, plus c'est la même chose. E, no entanto, o mundo passou por profundas transformações em meio século.

A população humana passou de cerca de 3,5 bilhões de pessoas para os atuais mais de 6 bilhões. Trata-se de um crescimento acelerado (associado ao progresso da medicina), que faz uma grande diferença no mundo. Multiplicaram-se instituições públicas internacionais, a começar pela ONU, revivendo a antiga Liga das Nações num patamar mais elevado, passando por FMI, Banco Mundial, FAO (na área alimentar), Unesco (na área cultural), OIT (Organização Internacional do Trabalho), GATT (hoje 
OMC, Organização Mundial do Comércio), entre tantas outras. Foram iniciados encontros periódicos dos governantes das potências políticas e econômicas, para tratar das questões mundiais - primeiro os do G7+1 (Estados Unidos, Canadá, Inglaterra, França, Alemanha, Itália, Japão, mais a Rússia), seguidos pelos do G20 (China, Índia, Brasil, México, entre outros). Na atualidade os dois grupos se reúnem num só. Em contrapartida às articulações governamentais, surgiram organizações da sociedade civil, como ONGs, grupos em movimentos sociais urbanos. Estes passaram a promover os encontros internacionais do Fórum Social, a ocorrerem na mesma época dos encontros do G7+1. Paralelamente, setores de movimentos sociais que se colocam contra "esta globalização" promovem manifestações ruidosas nas cidades onde há os encontros do G8 e do G20. Todos esses acontecimentos contribuem para a reafirmação do conceito de um sistema-mundo (WALLERSTEIN, 2009).

O avanço técnico e científico reflete-se em todas as instâncias sociais, originando um novo quadro civilizatório. Formulam-se novos princípios e conceitos, dá-se novo sentido a outros, alguns em contradição dialética. Por exemplo, indiferença, para enfatizar igualdades presentes nos gêneros e o merecimento de direitos comuns; diversidade, para acentuar a diversidade cultural das sociedades humanas. A justaposição de estilos produzidos em épocas diferentes, ou de meios diferentes, em obras de arte contemporâneas tem sido chamada de hibridismo e é uma das características do pós-modernismo. O termo, porém, pode ser aplicado em outras instâncias sociais, como na promoção explícita de mistura de componentes de modos de produção opostos numa mesma formação social. Como faz a China, promovendo a constituição de grandes empresas nacionais privadas, para a construção do que chama a economia socialista de mercado. Mimetismo, irreversibilidade (PRIGOGINE e STENGERS, 1984), incerteza (Heisenberg), caos ("Em toda realidade funciona a dinâmica que compreende um estado de desordem seguido de autoorganização e estabelecimento de uma nova ordem. Que acaba por se desfazer em novo caos, nova ordem e assim sucessivamente”, Edgar Morin) são tantos outros termos transportados das ciências físicas e biológicas para o campo social.

Atualmente, três quartos das reservas globais de petróleo se encontram em mãos de Estados, enquanto as irmãs petrolíferas, que estão entre as mais ricas empresas mundiais, atuam na produção e na distribuição por concessões ou contratos. Os controles do Estado e de seus bancos centrais sobre a economia assumem grande variedade de formas e de 
sofisticação que colocam o capitalismo sob rédeas. Trata-se de um quadro explicativo da aparente interrupção da gigantesca crise econômica e financeira mundial que se visibilizou em 2008. Que mostrou o governo americano injetando empréstimos de bilhões de dólares em bancos e empresas industriais privadas, em alguns casos por troca de ações, para evitar sua falência. Que mostra Estados comporem seus fundos soberanos, retirando reservas cambiais da circulação e influindo, desse modo, sobre o comércio e o valor das moedas. Mais do que isso, o quadro atual mostra atuações domésticas e internacionais conjugadas de Estados e de bancos centrais visando o controle do curso da economia mundial como um todo.

De outro lado, o quadro mostra um número de objetos que se tornam obsoletos; outros que mudam de funções ou que se elevam de plano depois de fases de hibernação. A antiga máquina datilográfica foi modernizada, eletrificada, mas não escapou de chegar praticamente a um fim, com a introdução do PC. A vitrola e seus discos de cera foram substituídos pelo CD. Em seguida pelo CD-ROM. Este, consumido em privacidade, atinge o cinema e as salas de ópera, afetando com certa perversidade práticas de sociabilidade.

O amigo e filósofo Fernando Cocchiarale traz as seguintes reflexões, comparando a história do cavalo e da arte. Com o aparecimento do automóvel, o cavalo perdeu praticamente a função de meio de transporte. Dele ficou a expressão HP (horse power), que compara a potência de um motor à força de certo número de cavalos. No entanto, o cavalo continuou sendo utilizado, em modalidades antigas e novas de equitação, como no esporte de polo, ou de turismo, como puxando coches de turismo no Central Park em Nova York etc. A arte, porém, mesmo com a adição dos novos meios, como o cinema, novos instrumentos musicais, continua mantendo o sentido de sempre.

Quanto à ressurgências e elevações de plano, citam-se exemplos de afloramentos de movimentos políticos e culturais que estavam latentes ou submersos pelo peso de forças de camadas hegemônicas. Nesses movimentos, os objetos se vestem de novas formas, ajustadas aos novos tempos; por exemplo: o movimento indígena de aimarás e quíchuas, nos Andes, adotando lemas do socialismo; a independência de um sem-número de países, inclusive a criação do Estado de Israel e a ressurreição do hebraico como língua viva; a ascensão do poder indígena nos Andes bolivianos; o movimento da China e das nações islâmicas que as recoloca na primeira linha do desenvolvimento mundial. 
O processo que compreende os fatos narrados nesta seção constitui um movimento de natureza histórica e geográfica que abrange focos e momentos, de imanência e de transcendência. Reconhecem-se cinco fases principais para esse movimento.

1. Da Guerra Fria ao condomínio americano-soviético. Finda a guerra, emergiram duas superpotências vitoriosas, Estados Unidos da América (EUA) e União das Repúblicas Socialistas Soviéticas (URSS), expondo a escala continental como uma referência do alcance de poder hegemônico. Organizou-se um mundo bipolar.

Acentuou-se o transbordamento da formação capitalista americana e de suas formas de planejamento sobre o mundo. A prevalência da força do capitalismo americano se manifestou no formato das novas instituições internacionais criadas após o conflito e na substituição do ouro pelo dólar como padrão de referência internacional para a paridade de moedas decisões iniciadas ainda antes do fim do conflito, na Conferência de Bretton Woods. Do outro lado, a URSS estendeu sua área geográfica de influência, cresceram os partidos comunistas na Europa Ocidental e difundiu-se o fermento socialista pelo mundo.

Antes de acentuarem suas divergências e entrarem numa fase de confrontações agudas, conhecida como Guerra Fria, as superpotências convergiram em importantes assuntos, como quanto a dar fim aos históricos regimes de impérios coloniais ou quanto ao banimento do fascismo explícito em literatura ou em estatutos societários. O confronto começou a ter forma definida a partir da luta pelo domínio político sobre a Alemanha e o bloqueio de Berlim ocidental pelos soviéticos.

Descolonização. A ideologia da descolonização se encontra nas raízes históricas das revoluções, americana e comunista. Na prática, a descolonização modertna serviria à expansão do capitalismo americano, de um lado, e à extensão da influência soviética, do outro. Seria impossível chegar à globalização com enormes áreas geográficas de alto valor econômico, fechadas e monopolizadas por metrópoles imperiais. Ter de pedir visto em Londres para visitar a Índia.

O desmantelamento colonial acarretou a independência de toda a África negra, dos países saarianos e subsaarianos, de países de uma faixa que se estende do Oriente Próximo ao Sudeste Asiático e à Austrália. No caso do império inglês já foi mencionada sua particularidade, dadas as vastas colônias de povoamento, Canadá, Austrália e Nova Zelândia, com 
elevados graus de autonomia e parecendo estados de uma Federação. Isso contribuiu para a saída mais tranquila da Inglaterra do regime colonial. No caso da França, a colonização com população francesa em regiões argelinas e vietnamitas se realizou em países com fortes culturas já estabelecidas, e as independências destes países se deu em meio a lutas sangrentas. O Canadá hoje aparece como um traço de união entre a Inglaterra e os Estados Unidos na política internacional.

A descolonização multiplicou o número de países árabes e de países islâmicos independentes e deu ensejo ao início da elevação do chamado mundo árabe e islâmico, a ator de primeira grandeza no atual quadro político mundial. A luta pela influência nesse mundo serviu de mais uma motivação da Guerra Fria. Na atualidade, esse mundo árabe e islâmico já é bastante forte para delinear o seu próprio percurso. Também no contexto desse espaço geográfico nasceu o Estado de Israel, com o voto das duas superpotências.

O Estado de Israel e o mundo árabe e islâmico. A Palestina era uma província otomana que passou ao mandato inglês outorgado pela Liga das Nações, após a Primeira Guerra Mundial. Já em 1917, antes do fim do conflito, atendendo a reclamos sionistas, a Inglaterra emitiu a Declaração Balfour, dizendo ver "com bons olhos a instalação de um lar nacional para o povo judeu na Palestina”. Os ingleses dividiram a Palestina otomana em Palestina propriamente dita, a oeste do rio Jordão, e Transjordânia, a leste. Nesta última foi estabelecido um reino, hachemita, que depois passou a se chamar Jordânia. A Palestina propriamente dita passou a ter uma área de cerca de 26 mil quilômetros quadrados, pouco mais da metade do estado do Rio de Janeiro. Em 1947, a ONU determinou a partilha desse país em dois, uma parte destinada ao Estado de Israel. Tratava-se, portanto, de um Estado minúsculo. Qual, pois, a razão de reservar amplo espaço para tratar deste assunto?

A questão árabe-judaica deflagrada com a criação do Estado de Israel é das mais centrais nas presentes tensões internacionais, sendo que Israel é presumivelmente uma potência atômica. Por outro lado, a criação de Israel contribui, de forma única, para a compreensão das possibilidades plurais, ao assumir uma permanência ideológica milenar. Ela ilustra o reaparecimento de uma instituição formal extinta há 1.940 anos. Além disso, a questão de Israel suscita questionamentos quanto a julgamentos de valor moral e ético sobre acontecimentos históricos atuais. 
Até o surgimento do Iluminismo e da secularização, a judeidade na Europa vinha sendo sustentada basicamente pela memória religiosa de linhagem de gerações que conduz aos patriarcas bíblicos; e pela resignação religiosa às perseguições anti-semitas. A partir do século XVIII, Iluminismo e secularização, além de atuarem para a inserção cidadã dos judeus no Estado moderno, influíram no surgimento de movimento políticos internos à judeidade. $\mathrm{O}$ fato de os judeus continuarem a ser vistos como corpo estranho por amplos setores das outras populações motivou movimentos políticos surgidos nas comunidades judaicas européias durante a modernidade, dirigidos ao sionismo, ao socialismo e ao comunismo. A visão comunista, propondo a dissolução de identidade nacional judaica, se ajustava à visão profética, do fim de todas as identidades nacionais. Substituía o movimento da conversão religiosa, ou de se assimilar pela cultura laica do país de nascimento, muito comum entre os educados, nos países ocidentais. Quanto ao sionismo, foi influenciado pelo descrédito numa solução utópica, acentuado pelo caso Dreyfuss, Ele nasceria justamente na Viena do Império Austro-Húngaro, afetado pelos movimentos de libertação nacional das chamadas minorias, como a tcheca, a húngara, a croata, a eslovena.

Sionismo e socialismo eram, pois, estratégias defensivas da judeidade. A assimilação total, com perda de identidade judaica, ocorria majoritariamente nas grandes cidades, nas camadas mais cultas, de classe alta e média, e nos países mais modernizados e desenvolvidos, como Inglaterra, França e Alemanha. Por outro lado, sionismo, socialismo e comunismo grassavam entre as camadas populares dos países menos desenvolvidos da Europa Central e Oriental.

Após a Primeira Guerra Mundial, tchecos, húngaros, poloneses, lituanos, entre outros, formaram seus Estados-nação. Sem referências ancestrais na Europa, o sionismo se voltou para a Palestina, com o propósito de instalar um Estado nacional judaico. Palestina era o nome imposto pelos romanos à antiga Judéia, depois da destruição de Jerusalém no ano 70 DC. Lá, desde a Antiguidade, fora mantida importante comunidade judaica. A Cabala foi desenvolvida na Alta Galiléia, em Safed, desde o século XI. No século XVIII e no início do XIX, no contexto do romantismo alemão, se estabeleceu uma corrente migratória de judeus da Alemanha e da Áustria para a Palestina, sem conotação política explícita. No fim do século XIX teve início a colonização sionista O primeiro kibutz, aglomerado agrícola industrial em regime socialista, Degânia, é do começo do século XX. Também a cidade de Tel Aviv está 
completando 100 anos. Nessa época conviviam na antiga Palestina duas comunidades, uma judaica de 80 mil habitantes, outra árabe de 300 mil, ambas sem identidade nacional estatal moderna. Uma se vinculava ao povo diaspórico judaico; a outra, à imá, a nação árabe estendida sobre o Oriente Médio.

Durante o século VIII deu-se a expansão árabe pelo Oriente Médio, África do Norte e Espanha. Essa expansão não se reduzia à colonização; ela compreendia a conversão de populações ao islamismo e à cultura árabe - inclusive de judeus. É provável que setores das comunidades judaicas na Palestina tenham se convertido ao islamismo durante as invasões árabes. Isso daria algum sentido à declaração de Arafat de que Jesus era palestino. Todavia, Jesus foi um judeu praticante, supostamente relacionado à seita dos essênios. Existem registros históricos quanto a um movimento messiânico judaico em meados do século XVII, liderado por Shabbetai Zevi, na Ásia Menor, e articulado com setores judaicos residentes na Palestina. Esse líder acabou se convertendo ao islamismo e assumiu um cargo no palácio do sultão; com ele, converteram-se muitos de seus seguidores (EBAN, 1984:216-218).

Embora organizados em clãs e reinos, e de viverem conflitos internos, os árabes mantiveram muito viva uma natureza comum às religiões monoteístas: a de que a um deus corresponde um povo. Am, povo/nação para a judeidade; umá para os árabes; nação cristã para a cristandade. No caso da cristandade, a separação entre a Igreja Romana e os ortodoxos de Constantinopla, depois o protestantismo, seguido da industrialização, da modernidade e da secularização, foram retirando o sentido nacional de povo cristão. A identidade associada à religião continua forte entre judeus e povos árabes e muçulmanos. O movimento da Al Qaeda de Bin Laden sustenta ao extremo o retorno do Califado para uma nação árabe restaurada.

A industrialização e a modernização européia, acompanhadas pelo desenvolvimento da forma de Estado-nação, de sua laicidade e de uma individuação crescente, distanciaram o mundo europeu do mundo árabe e muçulmano. Em 1918, o Império Otomano se reduziu de vez à Turquia. Nesta se esboçou uma reação, com a revolta de coronéis conhecidos como "os jovens turcos”, liderados por Ataturk, que estabeleceram a república e a separação do Estado da religião. Um problema atual do país consiste justamente no crescimento de partido que exerce forte pressão pela restauração da religião oficial do Estado. Quase todo o restante do mundo 
muçulmano, às vésperas da Segunda Guerra Mundial, estava subjugado pelo colonialismo europeu.

A divisão territorial política imposta pelos interesses do colonialismo europeu recobriu indistintamente divisões geográficas preexistentes associadas a distribuições de tribos e etnias locais. A política abomina o vácuo. Assim, a descolonização se fez com grupos proclamando independência e ocupando o poder de Estados ajustados às fronteiras coloniais. Logo surgiriam outros grupos lutando pelo mesmo poder, provocando um processo de consolidação de uma nova nação. Na África negra, em muitas regiões essa consolidação é débil, havendo lutas tribais sangrentas. No Oriente Médio, o Egito e a Síria ensaiaram unir-se numa república única, mas fracassaram. Também o Iêmen acabou dividido em dois Estados. Afinal, a umá na forma de um Estado/nação não se realiza apenas com pares de Estados. Por outro lado, o ingresso no capitalismo, em suas formas históricas iniciais, se realiza pela divisão em burguesias nacionais localizadas em cidades centrais. A herança de nação árabe, e de nação muçulmana, surgirá na formação de um bloco de países atuando coordenadamente em questões internacionais, numa época em que o mundo inteiro caminha para a formação de grandes blocos políticos e econômicos regionais.

Quando a ONU aprovou, em 1947, a partilha da Palestina entre árabes e judeus, e a internacionalização de Jerusalém, essa atuação árabe coordenada se manifestou na rejeição unânime da resolução pelos países árabes e muçulmanos. O Egito ocupou a Faixa de Gaza, e a Jordânia ocupou a Cisjordânia e a parte velha e oriental de Jerusalém. A parte velha continha bairros muçulmanos, judaicos, ortodoxos e armênios, e os monumentos mais venerados das religiões monoteístas, o Muro das Lamentações, parede remanescente do templo da época de Jesus, o Santo Sepulcro e a mesquita de Omar. Egípcios e jordanianos permaneceram nestas regiões até 1967, quando foram ocupadas por Israel durante a Guerra dos Seis Dias. Ao longo de 20 anos, não foram constituídas instituições nacionais palestinas nas regiões controladas por egípcios e jordanianos.

Vale lembrar que, apesar do empenho pessoal de Oswaldo Aranha, presidente da Assembleia Geral da ONU, em 1947, pela aprovação da partilha, o governo de Dutra levou anos para reconhecer Israel. O chefe de Estado de Israel, Ben Gurion, do Partido Trabalhista, de orientação socialista, foi o primeiro presidente da história a aparecer sem gravata e em 
mangas de camisa. Para defender sua existência, Israel recebeu armamento tcheco, portanto com anuência soviética. Para muitos, Israel se transformaria logo num satélite soviético.

Com a Guerra Fria, Israel acabou ficando na esfera americana, enquanto a União Soviética passou a dar apoio à causa árabe. As duas maiores comunidades da diáspora judaica eram a americana e a soviética. Ficou patente que, se a americana podia exercer pressão sobre a opinião pública, essa possibilidade não existia do lado soviético. Imiscuir-se num mundo muito mais populoso e rico em petróleo era muito mais rendoso para os soviéticos, que inclusive passaram a dar suporte oficial ao antissemitismo. Por outro lado, o capitalismo alcançou elevados níveis de desenvolvimento em Israel, ao lado de setores cooperativos socialistas. O país optou pela aliança com os Estados Unidos como saída de sobrevivência.

Com a ocupação de toda a antiga Palestina em 1967, particularmente após 1973, quando a ação militar egípcia levou ao primeiro recuo territorial de Israel, devolvendo o Sinai ao Egito, a resistência a Israel, nas mãos dos próprios palestinos, se intensificou. Eles passaram a desenvolver uma identidade nacional nos moldes do capitalismo e da modernidade. Israel, que inicialmente se viu em conflito com os países árabes, agora também enfrentava as reivindicações palestinas, além dos envolvimentos com a Guerra Fria.

O mundo árabe e islâmico formado de Estados independentes após a Segunda Guerra Mundial passou a ser tomado por diversos movimentos políticos e ideológicos. De forma resumida e esquemática se registram certas afinidades destes movimentos com a variedade de correntes presentes no centro e na periferia do mundo ocidental. A corrente associada ao crescimento de burguesias urbanas se aproxima dos modelos democráticas estáveis do Ocidente, quer na forma monárquica, caso do Marrocos, quer na forma republicana, caso da Tunísia. Em regiões de forte permanência da forma de clãs, na península arábica, mantêm-se antigos regimes de reinos e emirados. Da esquerda soprou o movimento marxista, que participou ativamente na luta pela independência na Argélia, aonde chegou a estar no poder. No Irã, os marxistas chegaram a governar, com Mossadegh, e a participar na derrubada do poder real iraniano. No entanto, condições objetivas, considerada particularmente a força da religião islâmica, impediram qualquer consolidação de regimes socialistas no mundo árabe ou muçulmano Os pequenos setores marxistas urbanos que 
apoiaram movimentos populistas, em geral sob liderança militar, como no caso do Egito, com Nasser, ou do Iraque, com Saddam Hussein, acabaram dizimados. Os movimentos populistas se alimentavam do descontentamento popular com o subdesenvolvimento e com a corrupção dos governantes. Os regimes populistas receberam o apoio da União Soviética, mesmo quando se livravam dos comunistas. A Guerra dos Seis Dias resultou do cerco militar de Israel promovido por Nasser com apoio soviético. No entanto, os regimes populistas também provocaram descontentamento entre suas populações. Somavam-se insatisfações, com a tendência à pratica autoritária e à perpetuação de um grupos no poder, com a tendência à corrupção impune, e com o laicismo praticado por esses regimes. O que fez crescer partidos religiosos e clericais no Islã, que uma vez no poder, como no caso do Irã, dirigido pelos aiatolás, imprimem a forma fundamentalista e a de um novo populismo. O mundo islâmico é dividido por seitas religiosas, em alguns casos coexistentes num mesmo país, fonte geradora de conflitos, como os que ocorrem atualmente no Iraque. $\mathrm{O}$ poder clerical do Irã sustenta movimentos fundamentalistas no Líbano e em Gaza. O movimento fundamentalista islâmico é forte no Egito, na Argélia e penetra a Turquia.

O desenvolvimento do fundamentalismo islâmico se inicia na época em que se dão o declínio e o desaparecimento da União Soviética. O mundo islâmico estava crescendo no quadro mundial em termos demográficos, econômicos e políticos. Um crescimento expresso no manejo político do petróleo, a partir de 1973; na ampliação do número de Estados islâmicos na Ásia Central, devido ao fim da União Soviética; no domínio da bomba atômica pelo Paquistão. Assim o desenvolvimento do fundamentalismo islâmico se junta ao desenvolvimento da China, da Índia, do Brasil, para dar novas formas ao quadro mundial. $\mathrm{O}$ fundamentalismo islâmico, dado seu compromisso particular com o passado, procura-se colocar à frente da ideia do retorno às antigas glórias do Islã e da expulsão da influência ocidental de todo o espaço geográfico tido como islâmico. $\mathrm{O}$ setor mais extremista nesse sentido é representado pela Al Qaeda, do líder sunita Bin Laden, que propõe o restabelecimento do califado.

Desse modo, a ascensão de partidos religiosos radicais agrava a questão palestino/israelense, uma vez que para eles é inadmissível antiga terra dominada pelo Islã ser cedida a infiéis. Além disso, a aceitação de Israel equivaleria à aceitação da penetração da modernidade ocidental no mundo islâmico. 
O mundo árabe e islâmico se encontra atualmente dividido entre as formas de modernidade globalizante e as de modernidade instrumental fundamentalista. A modernidade instrumental absorve a modernidade tecnológica ocidental, mas não o conjunto de seus valores sociais. O setor globalizante tende a aceitar uma solução negociada com Israel, porém, ante a presença da força fundamentalista, se vê obrigado a impor condições difíceis para esse país: particularmente, o retorno de descendentes de refugiados palestinos para o território israelense, e não para um futuro Estado palestino, e a devolução de toda a Velha Jerusalém.

A questão árabe/israelense expõe um profundo e interessante problema ético-político cujo julgamento de valor, em geral, tem sido embaralhado pela mistura de lógicas pertinentes às formas sociopolíticas atuais, com lógicas que apelam a sistemas antigos. A lógica dos sistemas atuais de Estados/nação é mais fácil de ser entendida e resolvida. De um lado, uma comunidade palestina estabelecida sobre um território há séculos, que adquiriu identidade nacional a partir dos anos 1970, e que legitimamente reivindica seu Estado. Do outro lado, uma comunidade judaica também estabelecida há séculos sobre o mesmo território, embora em menor número, que cresceu com imigrações maciças desde o começo do século XX, particularmente após a Segunda Guerra Mundial, e que também reivindica o seu Estado.

Os palestinos acusam a imigração judaica promovida por instituições sionistas, como forma de colonização imperialista. Os judeus argumentam que ela se realizou de forma legal e relativamente pacífica, num território que não dispunha de uma entidade nacional própria. Argumentam que, quando os alemães já estavam em El Alamein, foi a comunidade judaica que formou batalhões para o $8^{\circ}$ exército, o de Montgomery, enquanto o mufti de Jerusalém se encontrava em Berlim. Argumentam ainda que, na atualidade, a maior parte da sua comunidade já é nativa do país. Discutir a origem do sionismo é inútil, como seria inútil discutir hoje a legitimidade dos países resultantes da colonização das Américas. Uma vez que as duas comunidades se distribuem majoritariamente segundo regiões diferentes, cada lado reconheceria os direitos do outro e negociaria a divisão do território em dois Estados.

Contudo, apelando à lógica do passado, o argumento palestino é pela totalidade do território, sustentado por um clamor árabe geral, que relembra a forma antiga de nação árabe. Desde o século VIII, o território disputado era parte do grande espaço histórico e geográfico árabe. Do 
outro lado, os judeus religiosos ortodoxos revidam, lembrando sua presença no território desde os tempos bíblicos e a doação divina a seu povo. Os árabes chamam os judeus de racistas, por quererem um Estado judaico. Na verdade, a judeidade é multirracial. Sua originalidade consiste na manutenção da forma antiga de identificação de religião e nação Quem adere à religião judaica se torna automaticamente membro do povo judaico. Assim, os judeus respondem que uma Palestina seria mais um Estado/nação árabe, obedecendo em certa medida ao islamismo.

Amplos setores da esquerda mundial passaram a apoiar o radicalismo islâmico, na velha estratégia de sustentar qualquer movimento contrário ao centro capitalista e à globalização. Nos confrontos empreendidos por setores islâmicos com o mundo ocidental, aqueles contam também com a indiferença ou o apoio originado do pragmatismo interessado em negócios ou em criar dificuldades a concorrentes. No entanto é necessário cuidado com pragmatismos. Na obra citada no início deste trabalho, lê-se que "a consciência pode, às vezes, parecer mais avançada do que as relações empíricas contemporâneas, de tal forma que nas lutas de um período posterior possa-se apoiar nos teóricos anteriores como autoridades" (MARX e ENGELS, 1996:113). Encontra-se nas religiões monoteístas e na filosofia grega princípios críticos ao individualismo extremo, presente atualmente no capitalismo. No entanto, não se confunde individualismo com desenvolvimento do indivíduo, impedido em regimes teocráticos. Superar a divisão do trabalho, "Ser e Essência. Isto não é possível sem a coletividade e impossível sem o completo livre desenvolvimento do indivíduo que ele implica” (MARX e ENGELS, 1996:116-117).

- Diversidade, transmodernidade. A descolonização foi seguida de extravasamentos políticos e culturais a partir da periferia. Um movimento convergente com a expansão generalizada das atividades culturais pelo mundo e conjugado à maior mobilidade das populações. Massas de migrantes dos países periféricos passaram a se mover para o centro, massas de turistas dos países do centro passaram a visitar a periferia. O processo passou a expor a riqueza da diversidade da vida social no mundo, além de provocar conflitos, como os derivados da competição dos migrantes, oferecendo mão de obra mais barata. Ou, relacionados ao preconceito ativado pelos encontros.. Na esteira destes movimentos foram introduzidos novas idéias e posicionamentos políticos. O crítico literário Edward Saïd (2007) insistiu na hermenêutica do sentido próprio de cada cultura e trouxe o conceito da cultura do viajante, que trata de mudanças comportamentais do indivíduo resultantes de sua passagem por diferentes regiões em que 
passa a viver. A defesa da convivência de populações com profundas diversidades culturais e a manifestação do princípio da diversidade são traços da pós-modernidade. Atenuam o ideal homogeneizador da modernidade, retirando a idéia de um padrão cultural único para o mundo. O princípio da diversidade se inspira na evolução da biosfera, no desenvolvimento da vida no planeta. Esta se realizou com a proliferação de espécies, por meio de mutações, de hibridismos e de ajustes a ambientes ecológicos. Na natureza não se apresentam fronteiras impostas deliberadamente para separar as relações e a convivência entre os diversos. Foi o intercâmbio, a mobilidade, que fez a vida se desenvolver. As andorinhas não cessam de voar de um ecossistema a outro. Do mesmo modo, a história da diversidade cultural do homem é uma história de encontros e mixagens de raças e culturas e de ajustes a ambientes territoriais.

No entanto, o princípio da diversidade passou a ser utilizado por certos setores políticos como justificativa de formas de autoenclausuramento de nações - o que no fundo trava o movimento da diversidade, inclusive o da diversificação interna a cada nação. Por exemplo, quando se chicoteiam mulheres no Sudão por vestirem calças ou se executam homens no Irã por serem homossexuais. Certos setores marxistas caíram em contradição, aqueles que se posicionaram contra a pós-modernidade, devido à valorização que esta dá a uma diversidade oposta a uma homogeneidade modernista radical. Depois, oferecem apoio à utilização da diversidade como justificativa para o fechamento de nações por regimes tradicionalistas, contra a modernidade, desde que se coloquem em choque com a globalização e o centro capitalista. Não importa se tratar de uma marcha a ré e contrária ao internacionalismo. Na verdade a questão que se apresenta é a de como compor homogeneidade e diversidade necessárias.

No Brasil, a valorização da diversidade se manifestou em mudanças no posicionamento da sociedade e dos governantes frente às culturas indígenas remanescentes. Na época getulista, a ideologia oficial reclamava a aculturação dirigida dos índios. A perversidade era encoberta fazendo-se estudantes secundaristas cantar estrofes nativistas de Villa-Lobos, como "O canto do pajé”, nas comemorações da Semana da Pátria. Na atualidade, o consenso é deixar cada tribo decidir o quanto de aculturação ao padrão dominante deseja assimilar - um respeito que, contudo, não pode admitir qualquer retorno à antropofagia física. 
Antropofagia física, porque na Semana Moderna de São Paulo, de 1922, o Manifesto antropofágico, com Mário de Andrade. a antropofagia assume um sentido figurado de assimilação cultural. $\mathrm{O}$ atual processo indigenista boliviano também é ilustrativo de antropofagia cultural, ao lançar slogans socialistas, de ideologias políticas de origem ocidental, em meio a cerimônias em que se ascendem fogueiras da tradição indígena (ROCHA, 2008).

A nova geografia do sistema-mundo que se vem formando desde o fim da guerra, sob impulsos econômicos, políticos e culturais, tem tirado o sentido da antiga nomeação de um centro e de uma periferia e dando margem a termos novos e velhos, como Norte e Sul, Ocidente e Oriente. Uma nova escola de pensamento cultural surgiu com o movimento de desenvolvimento nas regiões periféricas ao antigo centro capitalista, a escola da chamada cultura pós-colonial. A ocupação do cenário mundial pela multitude de culturas originadas de todas as partes do planeta provocou a proposição do termo transmodernidade, inclusive como substituto para pós-modernidade (DUSSEL, 2002).

No plano nacional, o processo se manifesta na forma de nichos de cultura popular se elevando para ocupar lugar no espaço geral da cultura brasileira. É o caso de movimentos como o do Nós do Morro, alusão às favelas, ou do Afro reggae, também na cidade do Rio de Janeiro.

Alguns membros dessa escola chegam ao radicalismo político de considerar movimentos culturais sem vínculo com a cultura ocidental. Deixam de lado o fenômeno universal do intercâmbio e de formas de permanência do passado. Ignoram a influência marxista em setores indígenas na América do Sul, Mário de Andrade e a antropofagia.

A Guerra Fria. Finda a Segunda Guerra Mundial, os Estados Unidos emergiram como a única grande potência que escapou de destruições em seu território e com perdas relativamente pequenas de vidas. Passou a dispor de amplos espaços econômicos para a conversão da economia em tempos de paz, aparecendo como grande potência econômico-financeira e militar. Já a União Soviética perdeu milhões de vidas e sofreu gigantescas destruições. Enfrentando enorme escassez, voltou-se, na reconstrução, para as indústrias de base para manter sua condição de potência hegemônica. A estratégia americana para manter e ampliar espaços de influência fundouse em seu poderio econômico-financeiro e militar, vendendo seu modelo consumista; a da União Soviética, no proselitismo do socialismo e no suporte a movimentos contra os países hegemônicos capitalistas. No plano 
mundial, passou a atuar como grande potência militar. Alguns confrontos armados chegaram a ocorrer, envolvendo aliados das duas superpotências, como a guerra entre as Coreias, a do Norte e a do Sul (1953-56). No entanto, os dois protagonistas, apesar de alguns incidentes militares, nunca se enfrentaram belicamente.

Em 1948, os Estados lançaram o Plano Marshall, uma oferta de financiamento de mais de 11 bilhões de dólares (da época) para a reconstrução da Europa e do Japão. A URSS recusou participar e impediu sua aceitação pelos Estados satélites. O Plano deu suporte a um novo surto capitalista na Alemanha Ocidental, a ocupada pelas forças anglo-francoamericanas, e aprofundou o desnível econômico com a Alemanha Oriental. Os soviéticos intensificaram o levante de barreiras entre as duas Alemanhas, e a Guerra Fria foi deflagrada.

A Guerra Fria foi acompanhada por uma competição tecnológica em áreas estratégicas, como a corrida espacial, que do lado americano canalizou a produção de novos produtos para o consumo civil, como os utilitários na área automobilística e os PCs na informática. O mundo capitalista entrou em nova fase de acumulação, uma fase A de um ciclo Kondratieff (WALLERSTEIN, 2009). Multiplicaram-se as corporações transnacionais pelo mundo capitalista, em número e dimensão. Paralelamente, EUA e URSS estabeleciam blocos militares. A atual Otan (Organização do Tratado do Atlântico Norte), que participa das operações no Afeganistão, é a única remanescente dessa fase.

A formação dos dois blocos centrados na URSS e nos EUA não impediu desavenças internas e perturbações de percurso. Demonstrava-se a dificuldade de uma hegemonia única se impor. A França de De Gaulle, de tradições napoleônicas, não assimilava descer do nível hierárquico mais alto, ver a língua inglesa se tornar a língua internacional e Nova York substituir Paris como principal centro cultural mundial. Acabou se retirando da Otan, para a qual retornou recentemente pelas mãos de Sarkozy, seu atual presidente. No Leste, líderes carismáticos, como Tito, na Iugoslávia, e Mao, na China, não puderam aceitar imposições de interesse soviético e criaram cismas.

A Guerra Fria acabou rebatendo sobre todas as partes do mundo, mesmo quando ela já se arrefecia. Na América Latina, influiu no estabelecimento de regimes militares em todos os seus países, nas décadas de 1960-70. Esses regimes eram instalados no interesse das classes dominantes e com apoio norte-americano para debelar movimentos sociais 
e lideranças políticas simpáticas ao socialismo ou sem preconceito contra ele. O auge da Guerra Fria ocorreu em 1962, justamente na América Latina, quando a URSS de Kruschev, instalou mísseis em Cuba. Os EUA de Kennedy ameaçaram tirá-los à força, Com o recolhimento dos mísseis, iniciou-se uma fase de distensão gradual entre as superpotências, ambas demonstrando sua responsabilidade pelo destino do mundo, uma vez que cada uma passara a dispor de armamento nuclear capaz de aniquilar a civilização. Iniciou-se fase conhecida de distensão e de condomínio.

Sociedade afluente e Estado previdenciário. A ampliação da produção e o barateamento dos produtos conduziram o crescimento do consumo, a arma capitalista para enfrentar a maré ideológica comunista, particularmente na Europa Ocidental. Ampliou-se a distância em relação às condições de vida na Europa Oriental e na União Soviética. Outro instrumento foi a instituição do Estado previdenciário, fundado na criação de serviços públicos de atendimento social, seguros de saúde, de desemprego. Os mais fortes partidos comunistas da época, o francês de Thorez e o italiano de Togliatti, que quase alcançaram o poder pelo voto, começaram a recuar eleitoralmente. Por outro lado, o movimento popular pela ampliação das funções sociais do Estado não cessou mais nos países capitalistas. A questão da cobertura universal do acesso à saúde ocupou recentemente o centro da política interna norte-americana.

A campanha ambiental. Ao final da década de 1960 e começo da de 1970, ante o avanço da sociedade do consumo e retração dos partidos comunistas europeus, a esquerda ocidental ergue novas bandeiras contra o capitalismo. Uma delas, a do anti consumismo, critica o excesso do consumo como forma alienante. Ainda na atualidade existem setores de intelectuais que se recusam possuir e assistir TV - apesar de o acesso ao consumo compreender a maior inclusão de massas populares na vida social e nas suas qualidades.

A campanha anti consumista não teve maior efeito sobre as massas. Sucesso maior foi obtido ao se levantar a questão da poluição e das condições ambientais. Inicialmente, ocorreu a crítica à proliferação da circulação automóvel e a disputa entre humanos e automóveis pelo espaço urbano. Também não contribuiu para fazer diminuir o uso dos carros particulares. Logo, porém, questões como o congestionamento urbano e a poluição atmosférica ganharam campo nas preocupações das populações urbanas. Elas foram seguidas pelas preocupações com as condições gerais 
do ambiente planetário, sob a pressão da atividade econômica, em termos do esgotamento dos recursos naturais ou do aquecimento global.

A palavra poluição apareceu inicialmente na campanha promovida pela esquerda pela paz e contra a bomba atômica, quando os EUA detinham o monopólio da mesma. Falava-se dos perigos da poluição atômica. Depois, o termo foi generalizado. Atualmente se cita até poluição visual, no mal trato de paisagens. Em 1972, conferência internacional em Estocolmo mostrou a ascensão da questão ambiental no plano político mundial. A Eco 92, no Rio de Janeiro, reunindo multidões formadas de dignitários mundiais, políticos e religiosos, representantes de instituições científicas, ONGs, movimentos sociais urbanos, confirmava o adensamento político da questão ambiental.

Vários fatos convergiram para que um desenvolvimento iniciado como uma estratégia no confronto ideológico comunista/capitalista transcendesse e assumisse dimensão própria. Conta-se, a atuação de setores de economistas, como o passado Clube de Roma, preocupados com a escassez de recursos; a pesquisa de naturalistas sobre as condições dos ambientes geográficos; a ampliação do monitoramento ambiental, como a produção de dados sobre a camada de ozônio na estratosfera, a redução das geleiras, entre outros. Do outro lado, a urbanização crescente, inclusive nas regiões subdesenvolvidas, com seus problemas ecológicos, o surgimento de novos surtos epidêmicos, sinais de alterações climáticas, problemas crescentes de abastecimento de água para uma população que dobrou em número, nos últimos 60 anos. A questão ambiental ocupa, hoje, lugar central na agenda política.

No Brasil, mais uma vez, a tomada de posição ideológica imediatista, sem atenção dialética, fez certos setores da esquerda ziguezaguearem em torno da questão ambiental. De um lado se criticava o investimento industrial estrangeiro. De outro, no início dos anos 1970, quando lá fora se acusava a transferência de indústrias poluentes, como a siderúrgica e a química, para a periferia, isso passou a ser identificado como estratégia do capitalismo do centro para desestimular os anseios de industrialização na periferia. Quando um menino se instalou, por dias, sobre uma árvore, em Porto Alegre, para impedir sua derrubada, que daria lugar a um grande investimento imobiliário, a censura do regime militar não percebeu sua carga política e permitiu sua publicação na imprensa. A luz acendeu, e logo a questão ambiental ganhou espaço na esquerda (o setor político mais convergente por sua natureza), até atingir a dimensão atual, quando a ideia 
dominante é a de desenvolvimento econômico com cuidados ecológicos, em termos materiais e morais.

2. Do condomínio americano-soviético à globalização. Finda a crise dos mísseis (1962), o grau de tensão entre EUA e URSS foi se atenuando, e as duas superpotências passaram a atuar também, utilizando mecanismos de negociação da ONU, para impedir que os diversos confrontos mundiais pudessem degenerar numa guerra mundial,. A distensão abrindo a perspectiva da paz engendrou novos desenvolvimentos, uma nova geografia que levaria à globalização. Contraditoriamente, a bipolarização começaria a ceder justamente quando se organizava o condomínio, ante a reação, em outros países, à pretensão das duas superpotências. Os blocos militares liderados pelas superpotências passaram a dar lugar a mercados comuns de países. O comércio mundial e as corporações transnacionais cresceram enormemente, assim como a presença de novas classes sociais.

Mercados comuns de países. Logo depois da guerra, mercados comuns começaram a surgir paralelamente aos blocos militares, na Europa Ocidental e na Europa Oriental. Com a distensão, à exceção da Otan, os blocos militares pelo mundo passaram a se extinguir, enquanto começavam a se multiplicar blocos de países em mercado comum. Isso significava circulação mais livre de pessoas e mercadorias, taxas aduaneiras comuns no comércio com terceiros, políticas macroeconômicas ajustadas, visando evitar maiores desigualdades na inflação, nas contas públicas, nas taxas cambiais. O sentido do movimento foi o de outros países assimilarem o significado da escala geográfica para a emergência das duas superpotências e de imitá-las por meio dos tratados de mercado comum.

Desse modo, foi sendo reiterado um movimento histórico, universal, que conduz, simultaneamente, à formação de unidades territoriais políticas em escala geográfica crescente e a institucionalizações políticas supranacionais. O movimento é acompanhado de novas identidades assumidas por suas populações. A intensidade desses processos varia com as condições históricas nas diversas regiões mundiais. A União Europeia é o exemplo mais avançado, com uma moeda comum, o euro, e um parlamento eleito comum. Tendo começado como um bloco de alguns países da Europa Ocidental para tratar da economia em carvão e aço, hoje é uma união supranacional que abrange quase todos os países europeus. $\mathrm{Na}$ América do Sul, o Brasil se empenhou, desde o final dos anos 80, para formalizar o Mercosul, tornado realidade na década de 1990. Malgrado as dificuldades econômicas desse bloco, tendo em vista o grande 
desequilíbrio entre as dimensões brasileiras e as dos outros membros, ele continua mantendo alto significado político. Independentemente desse processo econômico, outras razões históricas conferem às populações da América do Sul elevado sentimento de identidade continental comum.

1968. Essa data tem enorme força simbólica, dados os fatos ocorridos em anos próximos a ela. Simboliza um conjunto de eventos que expressam o surgimento no cenário político de gerações nascidas depois da guerra, a partir do baby boom (empenho de jovens casais em procriar, antes do homem partir para o front), sua recusa a participar de guerras por áreas de influência, a insatisfação com as políticas externas e internas dos Estados dos dois campos, o capitalista e o socialista, voltadas para a manutenção burocrática das estruturas do poder de classes ou estamentos.

Nos Estados Unidos, onde Marcuse aparecia como guru, a guerra do Vietnã, o problema racial, o fundamentalismo burguês e religioso agitando os campos universitários. Surge o movimento hippie de "fazer o amor, não a guerra”. O amor é associado ao saber, glorificado no anúncio da Era de Aquário. Em agosto de 1969 acontece o festival de Woodstock. Um grupo pouco conhecido convida o público para uma espécie de piquenique nos arredores de Nova York, a fim de ouvir música e flanar. Mais de 100 mil pessoas apareceram nas primeiras horas do primeiro dia, de um total de 500 mil que participaram do evento durante três dias seguidos. Chovia e as multidões se deixavam cair na lama. A violência que imperava na guerra era "transformada em energia aplicada em instrumentos musicais, produzindo som forte, e na dança e encontro de corpos”, escrevia um jornal. Pela primeira vez o termo fuck, hoje tão frequente nos filmes americanos, é pronunciado em público. A crítica explícita à guerra do Vietnã é cantada por Joe McDonald em "I feel like I'm fixin' to die rag" ("Sinto que estou marcado para morrer").

Em maio de 1968, estudantes de Paris ocuparam ruas durante dias proclamando revolução contra o estado de coisas, o anacronismo nas formas de gestão do Estado, em geral, e da vida universitária, em particular. O movimento encontra apoio popular e produz alta ressonância internacional. No Rio de Janeiro ecoa no grande desfile pela democracia e contra o governo militar, na Avenida Rio Branco, liderado por estudantes e que reuniu cerca de 100 mil pessoas. Funcionários das repartições públicas localizadas no centro da cidade deixaram o trabalho e aderiram à manifestação, como os geógrafos do IBGE, Pedro Geiger e Fany Davidovich. 
Maio de 1968 em Paris tem significado particular por expor a fratura entre a esquerda tradicional, subordinada aos ditames de lideranças institucionalizadas, leais aos laços com Moscou, e novas esquerdas atuantes sob impulsos próprios e criticando a falta de liberdade nos países do Leste Europeu. O setor sindical, a CGT, não deu apoio aos movimentos estudantis e populares de Paris, por não tratarem de questões como salários, e sim enfatizarem questões culturais.

No Leste, 1968 é o ano da Primavera de Praga, episódio marcante na sucessão de rebeliões que passaram a ocorrer nas capitais dos paísessatélite contra a ocupação e a interferência russa em seus assuntos internos. Ela se seguiu a movimentos em Berlim, Varsóvia e Budapeste. A revolta de Praga alcançou maior significado porque a Tchecoslováquia, ao contrário das outras repúblicas populares, era uma sociedade regida por regime democrático, com grande presença de partidos socialistas, desde antes da guerra.

Enquanto os eventos narrados se manifestavam às claras, outras formas de movimento anti sistêmico reuniam grupos radicais em marginalidade e apelando para a violência. Os principais movimentos dessa natureza surgiram, coincidentemente, nos antigos países do Eixo Alemanha, Itália e Japão. A retórica era comunista, o nome dos grupos italiano e japonês era de Brigadas Vermelhas. Porém, não havia vínculos formais com partidos institucionalizados, da esquerda. É possível imaginar que esses grupos expressavam a grande confusão mental deixada pelo passado fascista daqueles países, que misturava slogans anti capitalistas e insatisfações nacionais. Agora eram insatisfação com a forma capitalista da reconstrução e com a hegemonia americana, com o arrefecimento da agressividade contra o capitalismo pela URSS, aderente do condomínio. A semente fascista pode ser reconhecida na forma violenta de atentados contra civis inocentes, como o praticado pelo movimento japonês no aeroporto de Tel Aviv.

O grupo alemão Baader-Meinhof, predominantemente de jovens, durou de 1967 a 1979. De um lado praticava a permissividade da nudez, do sexo, como os jovens de Woodstock. De outro lado se entregava à violência, em estilo fascista. No famoso sequestro de avião da Air France, levado por Entebe, à moda nazista os passageiros judeus foram separados dos outros. O grupo guerrilheiro teve papel destacado em contatar os movimentos armados árabes que estavam se formando na época e treinálos para as práticas terroristas. Não foi fortuito o fato de um de seus líderes, 
saído da prisão recentemente, ter aderido ao partido da atual extrema direita alemã.

Por todos os fatos tratados nesta seção, 1968 se tornou o marco de uma época de inflexão do movimento mundial, de critica ao mundo construído pela modernidade. A expressão pós-modernidade se populariza. Em 1967 ocorreu a Guerra dos Seis Dias, na qual a pequena Israel derrotou uma coligação formada por Egito, Jordânia, Líbano, Síria e Iraque, ferindo profundamente a autoestima árabe. A partir de então teve início um movimento de recuperação do orgulho nacional que abrangeria os países árabes e muçulmanos do Mediterrâneo e do Oriente Médio, até o presente. Como no caso das Brigadas Vermelhas e do Baader-Meinhof, o movimento islâmico espelha confusão entre práticas fascistas e práticas libertárias.

No Ocidente, nos países desenvolvidos, desde 1968 vem se acentuando a crítica sistemática à forma da democracia capitalista e à forma autoritária de regimes comunistas. Nos países emergentes do campo capitalista, o mesmo mimetismo entre práticas libertárias e práticas de autoritarismos fascistas preenchem movimentos populistas e nacionalistas. Isso põe em foco a falta de uma nova grande narrativa utilizando mecanismos de negociação da ONU para o futuro. A data de 1968 como que pariu um Esaú e um Jacó que precisam conviver.

A entrada do neoliberalismo. Nos anos 1960, o ritmo da acumulação capitalista passa a apresentar taxas decrescentes. De um lado aumentavam os gastos do Estado com campanhas militares em países periféricos, armamentismo, explorações espaciais, pesquisa e desenvolvimento científico, que não rendem retornos imediatos, custos previdenciários crescentes etc. Os serviços de saúde e ensino são inelásticos, em termos do tempo de sua realização, o que contribui para aumentar seus custos relativos. Sofisticar aparelhagens e medicamentos, equipar as escolas com laboratórios, bibliotecas e PCs não reduz os tempos gastos nas consultas médicas ou para a conclusão escolar. Por outro lado, o avanço da medicina, prolongando a duração média da vida, contribuiu para o aumento relativo da população idosa e para os gastos previdenciários com ela. Enquanto isso, a automação e a robotização introduzem força de trabalho que não recebe salário, não consome e não contribui para as contas públicas. Entre 1948 e 2008, a participação estatal nos gastos sociais subiu de 21,4\% para $38,6 \%$ nos EUA, de 30,4\% para 44\% na Alemanha, de 34,2\% para 47,6\% no Reino Unido e de 27,6\% para 52,7\% na França (STIGLITZ, 2009). 
Na luta pela apropriação de um excedente decrescente, setores da classe dominante passaram ao ataque, no sentido de impedir a extensão do Estado previdenciário. O alvo também incluiu nacionalizações de empresas privadas, como no caso das minas de carvão na Inglaterra. O argumento: uma vez que empresas estatais em vermelho não entram em falência, são cobertas pelo Tesouro, e seus trabalhadores passam a gozar de estabilidade, não há maior preocupação com a produtividade e com o empreguismo. Por outro lado, seus investimentos passam a depender, diretamente, da política governamental. Outra receita dessa corrente propunha a redução do Imposto de Renda, já que o Estado travaria seus gastos, para que o numerário fosse utilizado pelos capitalistas para investir e pelos trabalhadores para consumir. Propunha também fronteiras abertas para a circulação comercial e financeira. Toda essa linha se conformava com a idéia de um Estado mínimo, daí a designação de neoliberal.

A corrente conservadora ganhou o poder na Inglaterra com Margaret Thatcher na Inglaterra, nos anos 1970, e com Ronald Reagan, nos EUA, em 1980. Na Inglaterra as minas, que se encontravam no vermelho, foram privatizadas e assim permanecem até hoje, depois que os trabalhistas voltaram ao poder. O resultado do neoliberalismo foi "positivo", no sentido do crescimento da economia capitalista, da intensificação do comércio internacional e da ampliação do nível médio do consumo e da qualidade de vida. Abriu caminho para a ascensão de países emergentes e a instalação definitiva da globalização. No entanto, também conduziu para o aumento da desigualdade na distribuição da renda em países do centro e para a maior diferenciação de classes. Estimulou a expansão do consumo fundado no crédito, que seria uma das razões da grande crise econômica que estourou em 2008. O quadro neoliberal expunha a manutenção, ou crescimento, de amplos setores excluídos de suas benesses e com fraca proteção do Estado.

No Brasil, o governo militar instalado em 1964 justificava sua vinda para impedir a ameaça de um regime comunista e a estatização generalizada do país. Ele realmente travou expansão no setor previdenciário e de atendimento social. No entanto, ampliou enormemente o setor das empresas econômicas estatais e o de atividades de ensino e pesquisa de nível superior. Ante o crescimento da inflação, depois da redemocratização estabelecida em 1985, do débito público e da obsolescência dos serviços urbanos, algumas receitas do neoliberalismo foram implementadas a partir de 1994 pelo governo Fernando Henrique Cardoso. A privatização de empresas estatais da indústria e dos serviços 
urbanos, a imposição de equilíbrio entre receitas e gastos públicos e a maior abertura para o comércio exterior têm completado o Plano Real de estabilização da moeda, com resultados relativamente positivos para o crescimento geral da economia brasileira. A queda da inflação contribuiu para pequena melhoria na distribuição de renda; a privatização permitiu a universalização do serviço telefônico. Por isso foram mantidas em suas linhas gerais com a subida do PT ao poder. Quanto à permanência de grandes bolsões de exclusão e pobreza, o assunto foi alargado como alvo de políticas de proteção a partir da atuação estatal, no governo Lula, quando cerca de 12 milhões de famílias passam a receber o Bolsa Família.

Derivativos. Nos anos 1970, no front da economia capitalista, gestores do setor financeiro introduziam nova modalidade de jogo especulativo relativo a futuras cotações de divisas monetárias, commodities e outros valores. Tratava-se de fazer apostas sobre apostas já feitas, os derivativos. Essa modalidade de jogo se difundiu rapidamente pelo mundo, fazendo a economia virtual alcançar dimensões fantásticas. Em 2008, para um PIB mundial de economia real estimado em 50 trilhões de dólares, a economia virtual movimentava centenas de trilhões de dólares. Além de envolver fortunas de pessoas físicas e de instituições financeiras, o jogo dos derivativos atraiu instituições bancárias, cuja função precípua seria a de realizar empréstimos para os setores produtivos e para o comércio, a economia real. A grande crise de 2008 se iniciou no setor imobiliário americano, altamente financiado, e logo arrastou o setor financeiro. A economia é um sistema de vasos comunicantes; seus setores, real e virtual, são interconectados, de modo que a crise atingiu os dois, fazendo evaporar trilhões de dólares.

Nova estrutura de classe. A estrutura do trabalho e da sociedade mostra profundas transformações desde as últimas décadas do século $\mathrm{XX}$. Uma delas é o declínio absoluto e relativo da ocupação nos setores da produção industrial e agrícola de países desenvolvidos e emergentes, em favor dos serviços. Grande parte do trabalho industrial passou a depender da informatização, fundado na força mental aplicada em chips, transformada em automatização, robotização. Pesquisas sofisticadas são feitas em biologia, medicina, agricultura. As novas tecnologias da produção contemporânea tendem a dar suporte a trabalhos em equipe, porém, ao mesmo tempo, se prestam também à recuperação de “antigos valores das oficinas (...) nelas o ofício levava o sujeito a adquirir uma autonomia criativa e social” (SENNETT, 2009). 
Além de servirem aos setores próprios de pesquisa e desenvolvimento (P\&D) das grandes empresas, os serviços no interior das mesmas se estendem para atender seu crescimento em escala e sua expansão como transnacionais. Os serviços aumentam com a sofisticação da gestão pública, a multiplicação extraordinária de instituições acadêmicas e culturais, públicas e privadas.

O neoliberalismo acrescentou outro movimento, o da terceirização. Consiste no surgimento de empresas prestadoras de serviços banais para outras empresas, inclusive para repartições públicas, por intermédio de contratos, como serviços de limpeza e de transporte. Essas empresas utilizam mão de obra não qualificada, de baixa remuneração, subempregada. No Brasil, instituições públicas se liberaram da manutenção de frotas próprias de automóveis e de oficinas de reparos, via de regra ineficazes e fontes de corrupção.

Tais movimentos convergiram num processo que foi firmando uma nova estrutura para a sociedade e para o trabalho. Eles passaram a se constituir, respectivamente, em setor educado e não educado e em setor qualificado e não qualificado. Criou-se o conceito de capital social. Sua quantificação passou a ser adotada para avaliar os potenciais de desenvolvimento de lugares e países.

Capitalistas assalariados. Utilizando o princípio das afinidades eletivas, tomam-se emprestados termos de Michal Kalecki (1954) para propor uma nova composição de classe nas sociedades economicamente avançadas. A atual estrutura de classe seria composta de capitalistas, capitalistas assalariados e, simplesmente, assalariados. Capitalistas são os clássicos proprietários de meios de produção, dos quais extraem lucro. A categoria compreende milhões de pequenos empreendedores, cujo poder e riqueza são muito inferiores aos dos gestores de capital das grandes empresas. Estes últimos formam a categoria dos capitalistas assalariados. Ela reúne pessoas empregadas de corporações e de repartições e empresas estatais, nas quais atuam com elevada autonomia e alta remuneração. Os capitalistas assalariados assumem gestão e serviços de alta qualificação, como presidentes, diretores-conselheiros, pesquisadores, em troca de salário, bônus, jetom. O presidente da General Motors ou o da Petrobras são capitalistas assalariados. Alguns têm a faculdade de sugerir ou determinar quadros e salários das instituições. Já nos anos 1970 Henri Lefebvre sugeriu que o conceito marxista de capitalista deixasse de se restringir a proprietários de empresas e que levasse em consideração o 
nível dos ativos possuídos pela pessoa. Isso se aproximava do conceito americano de classe, baseado em categorias de rendimentos. Artistas e esportistas de fama, acadêmicos e pesquisadores ocupantes de altos níveis também alcançam essa categoria. Quanto aos simplesmente assalariados, eles formam categoria que aufere rendimentos para a reprodução de sua força de trabalho, basicamente.

A atual estrutura de classe espelha as tendências de hibridez contemporânea. A consciência dos capitalistas assalariados pode expressar, simultaneamente, o empenho pela acumulação capitalista e a defesa dos direitos do trabalho. É o que fazem tantos acadêmicos envolvidos em planejamento nos países capitalistas. Capitalistas assalariados transitam entre setores privados e públicos. Membros da equipe que produziu o Plano Real no governo de Itamar Franco vieram do corpo docente da PUC/Rio. Depois voltaram às aulas ou passaram a ocupar posições em empresas financeiras. Delfim Neto e Fernando Henrique Cardoso foram professores universitários que se tornaram expoentes na política e que alternam atividades acadêmicas com atividades empresariais e políticas.

A idéia de que uma classe dominada forçosamente se tornará a dominadora está ultrapassada. O mercador de Veneza, de Shakespeare, ilustra bem o fato de que na passagem do feudalismo para o capitalismo não foram os camponeses, mas, od mercadores e banqueiros das cidades emergentes que se aproximaram do poder. Do mesmo modo, na atualidade não é o proletariado, mas, são os capitalistas assalariados, nas corporações e no Estado, que galgam para as principais posições do poder.

Educados, não educados e monopolistas. Outra categorização social foi proposta definindo setores constituintes: um setor de população educada, um setor de população não educada e um setor de população empregada em setores monopolistas (RAJAN e ZIGALES, 2006). Os autores mostram a composição quantitativa desses constituintes influindo nas práticas políticas dos países.

O surgimento de novas formas nas estruturas sociais não significa o desaparecimento total das antigas. No Brasil, à margem da lei,, existem até nichos de trabalho escravo. O novo também pode compreender o retorno de formas assemelhadas a formas pretéritas. O trabalho individual com PC tem semelhanças com o do artesão. A sociedade se torna mais complexa e a hegemonia está se deslocando para setores novos. 
A geografia da globalização. Globalização significa uma nova geografia. A urbanização generalizada do mundo é uma construção resultante das formas de acumulação da globalização e um meio necessário à difusão da globalização. Efeito e causa. Para competir com o Japão pelo segundo lugar no mundo, quanto ao tamanho do PIB, a China transferiu cerca de meio bilhão de pessoas do campo para as cidades.

Um novo sentido de metropolização foi associado à urbanização contemporânea (BENKO, 2002; CLAVAL, 2005), que reconhece em cada país a divisão do sistema urbano em dois patamares. Um é formado de antigas e novas metrópoles, de cidades grandes, médias e pequenas, em crescimento acelerado. O outro é composto de cidades e regiões de crescimento fraco ou até negativo. Uma nova estrutura espacial é moldada em cada país.

Em termos da geografia regional e política, a antiga bipolarização entre EUA e URSS, seguida de um período de franca hegemonia americana, está sendo substituída por um mundo multipolar. É o resultado da evolução na localização de forças econômicas e sociais em países emergentes.

O quadro mundial apresenta um espaço liderado pelas potências capitalistas históricas - EUA e Canadá, Inglaterra, França, Alemanha, Itália e Japão. Apenas esses países reúnem em torno de 50\% do PIB mundial, para cerca de $10 \%$ de sua população. A eles se juntam outros, menores em área ou população, como Holanda, Bélgica, Espanha e Suécia.

Duas tendências políticas principais se movem nessa parte do mundo. Uma delas mostra populações ajustadas à situação hegemônica de seus países. Elas se dividem em torno das estratégias de gestão interna dos negócios e das maneiras de condução das relações internacionais. Nesse agrupamento há diversas correntes, desde as mais conservadoras e as que guardam antigos preconceitos raciais ou fobias contra imigrantes até as mais liberais, votantes de reformas mais socializantes. A outra tendência, que cresce nos EUA, é herdeira das tradições socialistas e das renovações culturais expressas em 1968. Ela sustenta a postura crítica permanente ao capitalismo, o pedido de mudanças profundas no regime econômico e social e soluções negociadas para os confrontos internacionais. É nesse bloco de opinião que se encontram os setores mundiais mais ativos da causa ambientalista. Ele também é dividido, apresentando um extremo de setores justificadores do fundamentalismo islâmico e seu terrorismo, enquanto outros conservam o compromisso com a democracia. 
Os sete países mencionados passaram a se reunir anualmente, a partir de fins do século passado, para avaliar o quadro mundial e traçar atitudes comuns. Por conveniência política incluíram a Rússia no grupo, que passou a ser designado de $G 7+1$. Seus dirigentes sofrem pressão dos movimentos sociais urbanos em seus países e nos países emergentes, por seu comportamento elitista. Os movimentos sociais criaram o Fórum Social, a realizar-se à mesma época dos encontros do G7+1. Este, então, passou a convidar para suas reuniões, de forma alternada, entidades, personalidades, dignitários de outros países.

Com a crise econômica de 2008-9, o G7 promoveu vários encontros, convidando outro grupo de países emergentes para formar o G20. Dele fazem parte o BRIC, o México, a Argentina, a África do Sul, a Arábia Saudita, a Turquia, a Coréia do Sul, a Austrália, a Indonésia, um representante da União Européia. Finalmente foi percebida a inutilidade da atuação particular de um G7+1, que está sendo substituído pelo G20.

Um segundo bloco de países é constituído pelos chamados emergentes, países de maior crescimento industrial e desenvolvimento social, que despontaram da antiga categoria de subdesenvolvidos e, depois, da categoria em desenvolvimento. Entre os emergentes também se destacam dois grupos, um deles designado de BRIC, constituído por Brasil, Rússia, Índia e China. O BRIC reúne países de dimensão continental ou subcontinental e populações acima da centena de milhões de habitantes. China e Índia somam 2,5 bilhões de habitantes. O PIB da China se aproxima dos 3 trilhões de dólares. O Brasil é hoje um grande celeiro para o mundo e já se apresenta como sede de um expressivo número de empresas transnacionais da área industrial, inclusive operando nos EUA. A China vem crescendo para se tornar o maior investidor na África, para a produção de matérias-primas. Paralelamente ao crescimento do PIB dos países do BRIC, cresce o intercâmbio entre eles. A China se tornou, individualmente, o segundo mercado das exportações brasileiras, após os EUA.

Alguns países da segunda linha dos emergentes, pelas dimensões territoriais e populacionais e pela influência regional, candidatam-se a participar do BRIC. Com o México, passaria a BRIMC; acrescentando também África do Sul, seria o BRIMSC.

Um aspecto particular é dado pelas relações entre os Estados Unidos e a China. Os investimentos das corporações americanas na China tornam os EUA a maior fonte de fluxos de capitais internacionais injetados 
maciçamente naquele país - enquanto os EUA são os maiores importadores de bens industriais da "fábrica” mundial que passou a ser a China, valendo-se de seus salários mais baixos. Os dólares do saldo de seu balanço de contas, a China investe em papéis do Tesouro americano. Com esses dólares, as contas americanas cobriam seus gigantescos débitos comerciais. Criou-se um cordão umbilical entre os dois países. Os dólares chineses não vão diretamente para as mãos do público americano, mas, sustentavam a confiança na economia americana e, desse modo, o comportamento consumista, a crédito, de sua população. Do outro lado, o investimento chinês sinalizava a manutenção do comportamento poupador chinês. Diversos economistas consideram esse quadro uma das raízes da atual crise econômica, por influir em desmedido no uso do crédito nos Estados Unidos, e por frear maior consumo chinês. Consideram indispensável a valorização da moeda chinesa e o aumento do consumo chinês para a recuperação do crescimento econômico mundial.

É no espaço dos emergentes que se realizam os mais enérgicos confrontos ideológicos atuais - não pela presença do comunismo na China. No momento, este país é apenas uma possível fonte latente de contradições futuras. Eles se apresentam nos movimentos do fundamentalismo islâmico, antissistêmico. A presença árabe e muçulmana no mundo representa 1,2 bilhão de pessoas. Ela se encontra também em movimentos nacionalistas e antissistêmicos na América Latina, como o chavismo venezuelano ou no movimento das Farc na Colômbia.

O Brasil mostra como os movimentos são dinâmicos e se modificam. Nos anos 1990, o Partido dos Trabalhadores (PT), um conjunto de alas esquerdistas e nacionalistas, inclusive de direita, liderava movimentos contra a abertura econômica do país, a globalização, o neoliberalismo. Em 2002, conquistou o poder, com Lula. Desde então o país passou a colher êxitos pela conjugação da manutenção de políticas globalizantes do governo anterior com a extensão de práticas compensatórias de renda, de assalariados e de pobres. A ampliação das exportações e a manutenção da atração de capitais externos, para investimento produtivo e especulação financeira, fizeram o país liquidar dívidas com o FMI e ainda acumular bilhões de reservas cambiais. O Brasil se tornou um pilar da economia globalizada, deixou de ser um mero latino sul-americano. Lula passou a ser o cara do mundo. As vozes críticas ideológicas mudaram o tom; passou-se a colocar em causa a forma de gestão da globalização pelas lideranças europeias e norte-americanas, o protecionismo a seus produtos, e expor ideias próprias de gestão mundial. Diante da crise, o Brasil (como a Rússia 
e a China) participa da reformulação do FMI e contribui com bilhões de dólares.

Um terceiro grupamento reúne países menos desenvolvidos, de base agrária. São exemplos extremos de subdesenvolvimento países como a Somália e o Haiti, onde a própria estabilidade nacional se vê em causa.

A geografia da globalização, à semelhança de um oceano percorrido por correntes quentes e frias, superficiais e profundas, mostra o encontro de movimentos que convergem e divergem. De um lado assiste-se ao desenvolvimento de tendências internacionalistas guiadas pela expansão capitalista, enquanto esta se vê compelida a assimilar componentes socializantes para poder sobreviver. Medidas socializantes são as que limitam a liberdade individual em nome do bem comum. Elas podem tomar $n$ formas e $n$ dimensões. É em torno desses enes que se realizam os atuais confrontos inter e intra classe. Controle ambiental, de salário mínimo e máximo, limites de riqueza individual, tamanho das coberturas de seguridade são exemplos de um mundo que se abre. Esses fatos levam a propor a seta da história tendo a forma de capitalismo > internacionalismo $>$ socialismo. $\mathrm{Ou},>$ socialismo de mercado, como querem os chineses?

O sentido desse desenvolvimento, porém, depende da superação de forças cegas, como as que provocam a destruição incontrolada do ambiente, a violência revanchista e a intolerância religiosa, a busca da hegemonia a qualquer custo, e que podem levar ao apocalipse.

\section{A metáfora dos três mendigos do Apocalipse}

Como metáfora, utiliza-se a figura dos três mendigos do Apocalipse para tratar de três forças magnas, desestabilizadores das atuais formas de vida social na Terra: o aquecimento global, a violência terrorista e a crise econômica.

1. O aquecimento global. Segundo setores de ecologistas, o planeta já estaria acusando uma elevação da temperatura média na superfície terrestre. O fenômeno decorreria da intensidade demasiada da atividade econômica e emanação de gases, acompanhada de destruição de florestas e provocando o efeito estufa. Os sinais estariam evidentes na retração das neves das altas montanhas, que desapareceram no emblemático Kilimanjaro, na África, ou na redução das calotas polares, sendo que a que cobre as águas árticas estaria perdendo espessura. Resulta disso a ameaça 
da elevação do nível do mar e da submersão de imensas áreas costeiras e densamente povoadas. A ameaça do aquecimento global compreende também redução de água potável disponível na Terra.

Recentemente, a notícia de que o rasgão produzido na camada de ozônio tinha se reduzido animou os céticos quanto à grandeza do problema. A camada funciona como um grande filtro dos raios solares, vital para a existência. No entanto, a questão ambiental, que inclui a poluição dos ambientes de vida humana e o esgotamento de recursos não renováveis, amplia espaços, para se tornar uma questão central. Os ambientalistas ainda se queixam de mais retórica da parte dos dirigentes públicos e menos ação necessária. Evidências, como imagens de TV mostrando ursos polares perdidos no oceano sobre blocos de gelo desprendidos, emocionam o público e pressionam governantes dos países do Norte. Está para terminar a vigência do Protocolo de Kyoto, assinado pela grande maioria dos países, definidor de medidas ambientalistas. Um novo acordo internacional estava sendo preparado para uma conferência em Copenhagen, que se realizou em novembro de 2009. Esperava-se total adesão de países, inclusive dos EUA, que não assinaram Kyoto, e que o acertado seja levado mais a sério. A perspectiva de milhões de cidadãos chineses aderindo aos padrões de consumo ocidental é um fato assustador que influi na preocupação ambientalista..No entanto, além de discursos de boa vontade, não se chegou a um tratado formal, adiado para outra conferência.

O Brasil está muito envolvido na questão, dada sua soberania sobre a maior parte da Amazônia. A mata atlântica foi quase totalmente destruída no processo do povoamento e colonização. Agora os esforços são para que isso não se repita com a floresta equatorial, o que seria um golpe fatal para a biodiversidade do planeta e sua significação para a vida. Tem sido mais fácil aplicar a legislação ambiental no caso de grandes projetos industriais do que quando se trata de conter produtores rurais dispersos por áreas de centenas de milhares de quilômetros quadrados.

A valorização da floresta em pé seria uma forma de ajudar a causa ambiental. "O Brasil já realizou, pelo menos, três revoluções (...) na exploração de petróleo em mares profundos, na transformação da cana-deaçúcar em álcool para fins energéticos e na expansão agrícola sobre o cerrado. É tempo para realizar uma nova (...) incluindo níveis de uso não predatório na floresta, como para a farmacologia e extratos” (BECKER, 2006:44). 
2. Violência, bomba A, e terrorismo. A violência é parte da natureza humana, do "mal estar da civilização". Porém, a história mostra o esforço de impor limites, disciplinar a violência. A civilização foi definida como "uma ordem social normativa, focalizando e canalizando impulsos humanos agressivos para a cooperação social pacífica” (TEHERANIAN, 2007).

Retrocessos têm sido observados, ocasiões nas quais a fera presente no homem se solta e a lei cega do mais forte prevalece. O nazismo representou tal fase, de modo coletivo, quando conduziu ataques a países para serem colocados a seu serviço. Correntemente, a violência coletiva ainda tem encontrado justificativa quando utilizada como forma de resistência e esgotadas as possibilidades de negociação. No entanto, justificativas revanchistas, ou posando de vítima, como fez Hitler em relação a Versalhes, lembram a estória do lobo e do cordeiro à beira do regato. A humilhação da Alemanha depois da primeira guerra não podia justificar os campos da concentração. Do mesmo modo, a quebra de regras alcançadas, mesmo para a guerra, pela prática do direito, não justifica retrocessos praticados pelas atuais formas de terrorismo. Quando atinge deliberamente vítimas inocentes em nome de resistência. Procedimento que acaba revelando o uso da resistência para mascarar outros intentos.

Há a distinguir a violência praticada sem recurso de uma doutrina sofisticada elaborada, daquela que se fundamenta numa grande narrativa (LYOTARD, 1998). As agressões de skinheads a imigrantes por motivos raciais, nas cidades do Ocidente, são odiosas, porém não têm consequências políticas maiores, uma vez que não se apóiam sobre estatutos formais. A questão da violência e do terrorismo do radicalismo islâmico reside justamente no fato de assumir pontos acima citados, transformando movimento de resistência em movimento com características fascistas.

Os grupos radicais islâmicos passaram a se organizar em partidos políticos e a redigir estatutos próprios. O Hamas, que tomou o poder na faixa de Gaza, e o Hezbollah, no Líbano criaram milícias armadas que desafiam e dividem o poder com o Estado. O estatuto do Hamas, por exemplo, que pode ser consultado na internet, ressuscita (paradoxalmente) o anti-semitismo europeu mais primitivo, citando Os Protocolos dos Sábios de Sion. O radicalismo islâmico revanchista recua aos valores do passado e prega a expulsão pela força de qualquer forma de presença ocidental, que chama de presença de cruzados. O fato de o movimento 
radicalizar também quanto à imposição de regimes religiosos é, porém, um dos seus pontos de fraqueza, dadas as rivalidades entre as seitas, como entre a sunita e a xiita.

As práticas terroristas inspiradas na fé e realizadas agora por partidos políticos reconhecidos, lhes deu um novo sentido, perigoso. Não se trata mais de simplesmente abrigar movimentos não estatais, como fez o regime talibã no Afeganistão com a Al Qaeda. Estados passaram a sustentá-los em interesse político próprio, reforçando um sistema de redes com apoio de governos reconhecidos internacionalmente - caso do Irã.

Os Estados Unidos carregam até hoje a marca de Caim pelas bombas-A lançadas sobre Hiroshima e Nagasaki em 1945. Que não se apagou apesar de Truman ter demitido Mac Arthur quando este sugeriu utilizar a bomba para acabar com a Guerra da Coreia. União Soviética, Inglaterra e França fabricaram suas bombas; depois foi a vez de Israel, China, Coreia do Norte, Índia e Paquistão. No entanto, a bomba se tornara uma arma dissuadora de guerras entre grandes potências. Nunca mais foi usada. O receio da proliferação na produção da bomba trouxe o conceito de países responsáveis e não responsáveis. O conceito de responsável, elaborado pelos primeiros possuidores da arma, se funda na sua contenção já demonstrada, na força das suas sociedades civis contra o uso da bomba, na inclinação demonstrada pelos seus governos para negociar etc. Foi criado também um tratado de não proliferação, para garantir que pequenos Estados não entrassem numa corrida atômica, de uns contra os outros. Israel não se declara nem desmente ser potência nuclear. Não faz alarde, para não chamar a corrida atômica para a região e se previne, estando cercado por países hostis, alguns Estados advogando a sua extinção. Se não faz alarde, é justamente para não chamar atenção.

Com o crescimento de atentados praticados por suicidas, a serem recompensados no Paraíso, a chamada “cultura da morte”, percebe-se que a ameaça do revide pode não mais intimidar um possível agressor atômico, principalmente se partir de um grupo terrorista, sem que se possa provar o local de origem. Esse é o grave problema político vivido atualmente no mundo e que gira em torno das pretensões iranianas de dominar a tecnologia atômica. A possibilidade da capacidade nuclear ser utilizada através de redes não governamentais e capaz de envolver a todos.

3. Crise econômica. Uma grande crise econômica e financeira começou a dar sinais ao final de 2007, nos Estados Unidos, iniciada com uma inadimplência ampla de compradores de imóveis a longo prazo. É 
comum o financiador tomar o bem hipotecado quando as prestações deixam de ser pagas. O bem é então revendido ou leiloado. Quando, porém, não há mais compradores, ocorre a crise. Os imóveis tinham sido vendidos com ampla promoção a juros baixos, pós-fixados. Quando os juros subiram, em muitas regiões o valor de cada imóvel ficou inferior ao montante que restava a pagar, passando a ser melhor abandoná-lo. Era o estouro da bolha imobiliária.

A crise imobiliária se propagou por todos os setores em grande rapidez, alimentada logo pelo setor financeiro virtual, e fazendo evaporar trilhões de dólares. David Harvey viu a crise como sendo de natureza estrutural, por ter se iniciado justamente no setor urbano - e no setor do crédito das famílias. Outros a viram como uma falha de gestão do setor público. Foi o governo federal quem instigara o público a adquirir imóveis por intermédio de financiadoras, com presença pública, a juros baixos, sendo ele quem controla a taxa básica de juros. Quanto à rápida propagação da crise, ao se articular com o setor financeiro, o governo foi acusado de não ter providenciado regulações adequadas ao jogo dos derivativos, o que permitiu a participação de bancos comerciais na especulação com derivativos. A verdade deve estar nos dois lados: uma crise com raízes estruturais e má gestão - uma estrutura que mostrou crescimento de desigualdades na distribuição da renda, enquanto declinava a poupança e crescia o consumo na base do cartão de crédito.

Devido ao estrago provocado, que se propagou pelos setores produtivos, que contaminou muitos outros países, e pelo fato de se ter iniciado no coração do capitalismo, a crise foi comparada àquela iniciada em 1929, que só terminou ao fim da Segunda Guerra Mundial. Mas também se constatam grandes diferenças. Uma delas é o papel e a força do Estado para enfrentá-la desde seu início. Outra é a atuação conjugada dos principais países do mundo para debelá-la.

Em 1932 Roosevelt foi eleito nos Estados Unidos e passou a aplicar receitas keynesianas, ampliando investimentos públicos, como no caso do Programa do Tennessee Valley; criou o sistema da seguridade social, Social Security. Do outro lado do Atlântico, a partir de 1933, Hitler tratava de recuperar a bacia carbonífera do Sarre, investir em projetos armamentistas, incentivar o uso do automóvel e construir rodovias, que serviriam, também, para agilizar conquistas de outros países e de seus recursos econômicos. E tudo acabou em guerra. 
Agora a crise vem contribuindo para uma postura mais internacionalista do G7 e do G20, no sentido de seus governantes acertarem medidas coordenadas para enfrentá-la. Para tanto, os Estados dispõem hoje de sistemas muito mais sofisticados quanto à qualidade, à quantidade e à rapidez na produção de informação, permitindo rápidas decisões no acompanhamento da crise.

Por outro lado, as decisões que foram tomadas, inclusive nos Estados Unidos e na Inglaterra, são ricas em aspectos socializantes. Somas maciças de dinheiro público, da ordem total de trilhões de dólares, foram injetadas em instituições financeiras e industriais privadas, como empréstimos, em troca de controles de ações e interferência nas administrações. Ao mesmo tempo, ampliou-se a proteção dos haveres bancários dos cidadãos, uma das formas de garantir consumo.

Não faltaram debates acirrados, com segmentos conservadores defendendo a velha norma de que, se uma empresa foi mal administrada, que vá à falência, pois outra ocupará seu lugar - porém, depois de um tempo indeterminado, enquanto milhares ficarão desempregados. A linha socializante tem levado a melhor, inclusive com o Estado se envolvendo na administração de empresas nas quais aplicou recursos.

Em crises passadas no Brasil, a grita contra a ajuda do Estado à empresa privada veio da esquerda, contra "a socialização dos prejuízos" mesmo quando se tratou do acesso de bancos ao Proer, um fundo de reserva formado obrigatoriamente com parte dos depósitos dos próprios bancos como instrumento de combate à inflação.

Nos Estados Unidos, na esteira da crise, novas questões sociais entraram na agenda política, enquanto outras são retomadas. Propõe-se a fixação de salários e de prêmios máximos para os gestores das corporações privadas e dos altos cargos públicos. É possível imaginar um dia em que também se fale de um limite para a riqueza individual. O tema da cobertura da proteção de saúde para toda a população também voltou a ocupar lugar central na política daquele país.

No Brasil, o governo Lula, desde antes da crise, se empenhou em melhorar a distribuição da renda e o consumo, por meio de aumentos do salário mínimo acima da inflação, empregos públicos e Bolsa Família. Criou-se um amplo estrato de baixa classe média. Aparentemente esse fato, somado ao crescimento dos intercâmbios no nível dos emergentes, suavizou a crise no Brasil. 
As novas formas de intervenção dos Estados na economia privada e de cooperação dos mesmos frente à crise dão sinais de que, como depressão, ela pode ser freada. A crise de 1929 causou o desemprego de $40 \%$ da força de trabalho nos Estados Unidos; agora não chegou aos dois dígitos. No segundo semestre de 2009 já despontavam sinais de crescimento econômico em diversos países e setores. A questão é saber o que ela significa como marco de uma nova transição da formação econômica e social mundial.

A crise não parece anunciar o colapso do sistema capitalista. No entanto, independentemente de uma atribuição estrutural ou de gestão, ela vem acompanhada de fatos novos nesses dois campos. Nos Estados Unidos só se ouviu a palavra socialismo ser pronunciada tantas vezes em corredores de instituições federais durante o macartismo. Era para execrar, difamar, acusar, condenar. Hoje, porém, é para reclamar, discutir, resistir ao que parece ser o anúncio de uma nova fase de intensa hibridez entre capitalismo e socialismo.

Para que a civilização vá adiante, contudo, é necessário o mesmo entendimento internacional para impedir o acesso dos outros dois mendigos.

\section{O MUNDO NO QUAL O BRASIL SE INSERE HOJE:} CAPITALISMO, INTERNACIONALISMO, SOCIALISMO.

Resumo: Este artigo parte da análise da formação do capitalismo globalizado e do debate internacionalismo-socialismo para compreender a inserção do Brasil neste processo.

Palavras-chave: Brasil; Capitalismo; Internacionalismo; Socialismo.

THE WORLD IN WHICH BRAZIL IS INSERTED TODAY: CAPITALISM, INTERNATIONALISM, SOCIALISM.

Abstract: This article aims to analyse the insertion of Brazil into the process of capitalistic globalization, developed through the changes of internationalism and socialism.

Keywords: Brazil; Capitalism; Internationalism; Socialism. 


\section{BIBLIOGRAFIA}

BECKER, Bertha K. (2006). Réflexions sur géopolitique de la logistique du Soja en Amazonie. La Geographie, Paris, Société de Géographie, n. spécial (Brésil), hors-série 1521, p. 36-45, set.

BENKO, Georges (2002). Mundialização da economia, metropolização do mundo. Revista do Departamento de Geografia, Salvador, UFBA, n. 15, p. 45-54.

CASTELLS, Manuel (1989). The informational city: information technology, economic restructuring, and the urban-regional process. Londres: Blackwell.

CLAVAL, Paul (2005). Metropolização e globalização. Cidades, Presidente Prudente, Grupo de Estudos Urbanos, AGB, v. 2, n. 3, p. 13-36.

DE LAURENTIS, Dino (1949, Itália). Arroz amargo. Filme.

DELEUZE, Gilles; GUATTARI, Félix (1992). O que é a filosofia? São Paulo: Ed. 34.

DUSSEL, Enrique (2002). World system and transmodernity. Neplanta: views from South, Duke, Durham, v. 3, n. 2, p. 221-244.

EBAN, Abba (1984). Heritage civilizations and the Jews. Nova York: Summit Books.

FREUD, Sigmund (1975). O mal-estar da civilização. In: Obras completas, v. XXI. Rio de Janeiro: Imago.

HARDT, Michael; NEGRI, Antonio (2001). Império. Rio de Janeiro: Record.

HEIDEGGER, Martin (1966). Introdução à metafísica. Rio de Janeiro: Tempo Brasileiro.

KALECKI, Michal (1954). Teoria da dinâmica econômica [Theory of economic dynamics]. In: Os pensadores, v. XLVII. São Paulo: Abril, 1976.

KUBRICK, Stanley (1968, EUA). 2001, uma odisseia no espaço. Filme.

LEFEBVRE, Henri (1947). Logique formelle, logique dialectique. Paris: Editions Sociales.

LYOTARD, Jean François (1998). A condição pós-moderna. São Paulo: Ed. 34. 
MARTIN, James (Ed.) (2008). The Poulantzas reader: marxism, law, and the State. Londres: Verso.

MARX, Karl; ENGELS, Friedrich (1996). A ideologia alemã (Feuerbach). São Paulo: Hucitec.

PRIGOGINE, Ilya; STENGERS, Isabelle (1984). A nova aliança. Brasília: UnB.

RAJAN, Raghuram; ZIGALES, Luigi (2006). The persistence of underdevelopment: institutions, human capital, or constituencies? NBER World Paper Series, Cambridge, National Bureau of Economic Research, mar.

RANGEL, Ignácio (1981). A história da dualidade brasileira. Revista de Economia Política, São Paulo, v. 1, n. 4, p. 5-34, nov./dez.

RENOIR, Jean (1937, França). A grande ilusão. Filme.

ROCHA, Erik (2008, Brasil). Pachamama. Filme.

SAÏD, Edward W. (2007). O Oriente como invenção do Ocidente. São Paulo: Companhia das Letras.

SENNETT, Richard (2009). Futuro de artífices da técnica e da mente. $O$ Globo, Rio de Janeiro, 6 jun.

SERENI, Emílio; LUPORINI, Cesare (1974). El concepto de formación económico-social. Buenos Aires: Siglo XXI.

SOJA, Edward (1993). Geografias pós-modernas: a reassunção do espaço na teoria social e crítica. Rio de Janeiro: Zahar.

STIGLITZ, Joseph E. (2009). Fetichismo do PIB. O Globo, Rio de Janeiro, 30 set.

TEHERANIAN, Majid (2007). Rethinking civilization: resolving conflict in the human family. Londres; Nova York: Routledge.

WALLERSTEIN, Immanuel (2009). Mudando a geografia do sistemamundo (1945-2025). In: SADER, Emir; SANTOS, Theotônio dos (Org.). A América Latina e os desafios da globalização. Rio de Janeiro: Ed. PUC-Rio. p. 54-76.

WOOD, Ellen Merksing (2000). A origem do capitalismo. Rio de Janeiro: Zahar.

ZENIN, Jiang (2002). Reforma e construção da China. Rio de Janeiro: Record. 